\title{
Somatic Condition, Growth and Reproduction of Hake, Merluccius merluccius L., in the Portuguese Coast
}

\author{
Ana Maria Costa \\ Divisão de Gestão e Recursos da Pesca, \\ Instituto Português do Mar e da Atmosfera, Lisbon, Portugal \\ Email: amcosta@ipma.pt
}

Received September 4, 2012; revised October 18, 2012; accepted November 9, 2012

\begin{abstract}
Weight/length relationships, condition factor, gonadosomatic and hepatosomatic indices, conversion factor for gutted to total weight and spawning season of hake in the Portuguese Coast (36.92 to 42.22 degrees latitude N; 9.61 to 6.07 degrees longitude W) were investigated for the first time, aiming to fill the lack of information on the biology of hake of the Portuguese waters. Data were obtained from commercial samples collected between 2005 and 2010 and pooled by month. Sex ratio observed in fish below $40 \mathrm{~cm}$ was close to 1:1; females were always dominant above $50 \mathrm{~cm}$ length. All the parameters were analysed by month and by sex and by combined sexes. The relationships obtained for combined sexes for the entire period concerning the growth in length and weight were: total length-total weight $=0.0038 \mathrm{~L}^{3.172}$, total length-gutted weight $=0.0052 \mathrm{~L}^{3.059}$. The relationship total weight-gutted weight was $\mathrm{W}_{\mathrm{t}}=15.8112+0.8480 \mathrm{~W}_{\mathrm{g}}$ and the conversion factor was of 1.1524. The growth rate is similar for both sexes but different when based on total weight or gutted weight. The analysis of the condition factor, gonadosomatic index, hepatosomatic index and the monthly distribution of the maturity stages seem to indicate that hake from the Portuguese Coast has a long spawning season, with three spawning peaks in March, May and August but the start of the spawning season seems independent of the fish length.
\end{abstract}

Keywords: Merluccius merluccius; Portuguese Coast; Biology; Somatic Condition; Spawning Season

\section{Introduction}

The main target of the investigation of the marine resources is to give new information on the biology and dynamics of the explored populations, by knowing the life cycle and biological characteristics (e.g., recruitment, spawning biomass and fishing mortality) of the species, in order to determine the real conditions of those resources (Piñeiro, 2011) [1]. Two important nursery areas for European hake have been identified north-east Atlantic waters (ICES, 1996) [2]: one area is located off the French coast in the Bay of Biscay and is known as "Le Grand Vasiérè" and another one is in the Celtic sea between the south-west of England and southeast of Ireland; there is no such information for Portugal.

Several technical measures are taken to manage the stocks status. In Portugal those management measures are based on information given by the National Biological Sampling Program, co-financed by the EU within the Data Collection Framework (PNAB-DCF), on the landing composition (by sampling at the fish market), discards at sea (with scientific observers on board commercial vessels) and biology (from biological sampling at the laboratory). Indices of abundance and recruitment are obtained by the research surveys (acoustics, demersal and crustaceans) carried out by IPIMAR (Instituto de Investigação das Pescas e do Mar).

Hake in Portuguese coast is caught mainly by the polyvalent fishing (hooks and purse seine) and trawl, together with some other species of fish and crustaceans: horse mackerel (Trachurus trachurus), monkfish (Lophius spp.), megrim (Lepidorhombus spp.), chub mackerel (Scomber colias), Atlantic mackerel (Scomber scombrus), blue whiting (Micromesistius poutassou), shrimp (Penaeus spp.) and Norway lobster (Nephrops norvegicus). An important feature about hake is the fact that most of the larger individuals are landed gutted because ovaries get a very high price at the fish market.

In Portugal hake is studied since the middle of the 1960 decade (Monteiro and Dias, 1965 [3]; 1966 [4]) and several papers have been produced since then regarding many different areas, much of them related to abundance and distribution of adults, eggs and larvae (Cardador, 1995 [5]; Ibaibarriaga et al., 2007 [6]), fisheries, stock assessment and selectivity (Campos and Fonseca, 2003 [7]; Cardador, 1988 [8], 1991 [9]; Dias and Cunha, 1984 [10]; Fonseca et al., 2005 [11]; Moura and Cardador, 
2005 [12]; Santos et al., 2002 [13]) and recruitment (Caramelo, 1983 [14]; Cardador et al., 2005 [15]; Mendes et al., 2008 [16]). Although in the beginning of the eighties years Marecos et al. (1982) [17] have developed some work on age and growth of the Portuguese hake, only later the biological study of the species increased, with particular interest on age and growth (Godinho et al., 2001 [18]; Jardim et al., 2004 [19]; Salgado et al., 2003 [20]) and maturity (Costa et al., 2009) [21], with special reference to the first microscopic maturity scale proposed by Gonçalves et al. (2004) [22] for the portuguese component of the Southern stock of hake, similar to the one used by IEO (Instituto Español de Oceanografía) that also studies the same hake stock, and implemented to distinguish correctly immature from resting females (Costa and Gonçalves, 2009 [23]; Costa et al., 2009 [21]), which are, as for many other species, not possible to distinguish macroscopically (Domínguez-Petit, 2007 [24]; Saborido-Rey and Junquera, 1998 [25]). Some other subjects have also been studied by Portuguese researchers, like parasites (Marques, 1985 [26]; Silva, 1984 [27]), feeding (Cabral and Murta, 2001 [28]; Hill and Borges, 2000 [29]) or lipid content (Gonçalves et al., 2004 [30]).

In the bibliography there are no references to important issues on the Portuguese hake, such as, sex ratio, physical condition or length-weight relationships. Therefore, the aim of this paper is to present the results of a biological study on the reproduction of the hake of the Portuguese coast for the last six years, based on the length distribution of captured fish, sex ratio, total length-total weight and total length-gutted weight relationships and the conversion factor between total and gutted weights. The somatic condition of the individuals was assessed by the condition factor, the gonadosomatic and the hepatosomatic indices and the spawning season was identified by the annual evolution of the maturity stages and the monthly changes in the gonads weights.

\section{Materials and Methods}

This work reports the results of the analysis of a 6-year time series (January 2005-December 2010) of some of the biological parameters that characterize the physical condition and reproduction of the Portuguese hake.

Our study was based on two sources of data:

1) random samples collected from landings at 12 fishing ports distributed by the portuguese NUTS II: Matosinhos and Póvoa do Varzim (North), Aveiro and Figueira da Foz (Center), Nazaré, Peniche, Sesimbra and Setúbal (Lisbon and Tagus Valley), Sines (Alentejo), Portimão, Olhão and Vila Real de Santo António (Algarve), which location is shown in Map 1.

2) samples collected by IPIMAR technicians on board

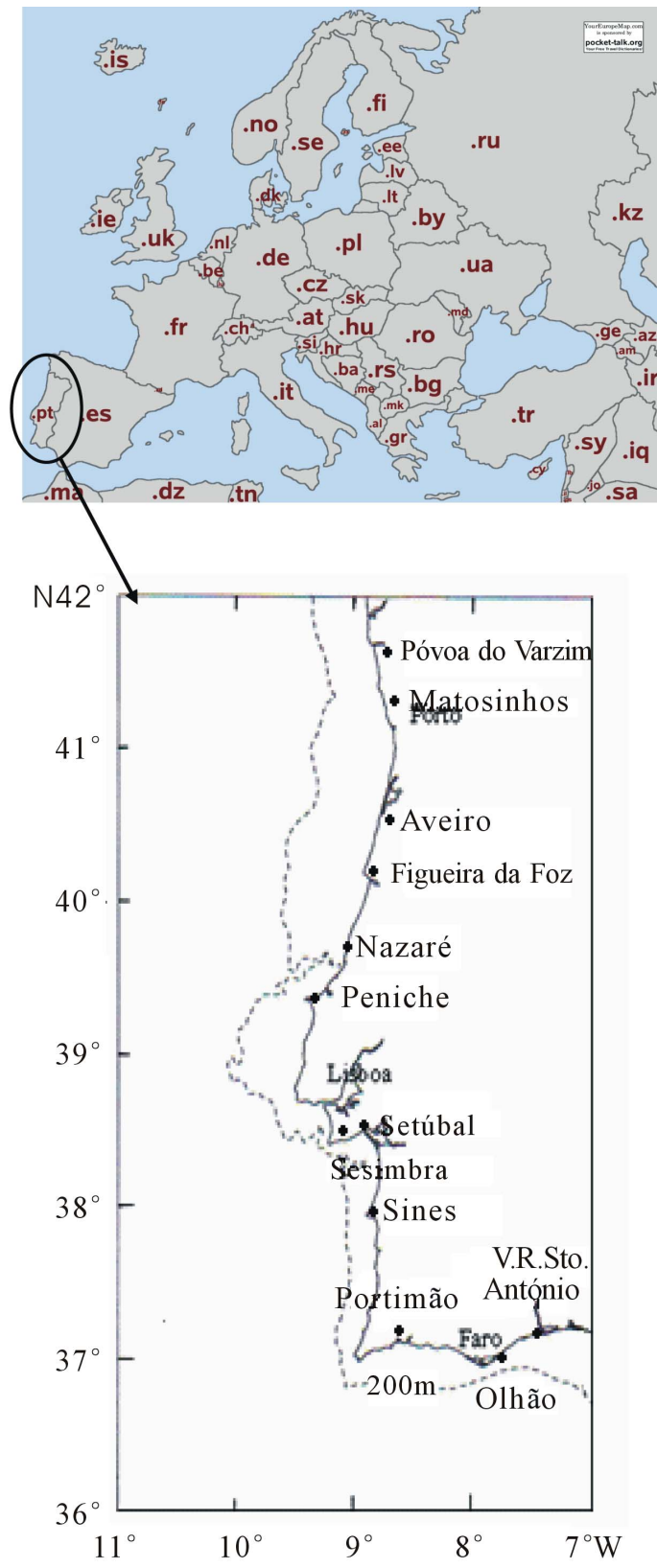

Map 1. Geographical distribution of the portuguese fishing ports where hake biological sampling was carried out in the period 2005-2010.

of commercial vessels operating in this sea area, in order to obtain information on the smaller individuals rejected to the sea by the fishing fleet.

In total 8212 samples were collected and after being screened to exclude those presenting sampling errors, such as total weight lower than gutted weight, 4935 were analysed. Given the large amount of information, impossible to present entirely in this kind of work, annual data were pooled by month and dealt by sex and by combined sexes, since hake stock assessment is based on combined sexes. 
The number of individuals caught by year and the correspondent length range is presented in Table $\mathbf{1}$.

When possible the data collected from each sample were: total length $(\mathrm{cm})$, total and gutted weight $(\mathrm{g})$, sex, maturity stage and gonad weight $(0.1 \mathrm{~g})$. Since many of the fish over $40 \mathrm{~cm}$ are usually gutted, total weight, sex, maturity stage and gonad weight of 1395 individuals were not recorded. Data were pooled by month.

Weight-length relationships were estimated by fitting an exponential curve, $\mathrm{W}=a \mathrm{~L}^{b}$, to the data (Ricker, 1973 [31], 1975 [32]). Weights and total lengths were logtransformed and the parameters $a$ (the initial condition factor) and $b$ (the allometric coefficient) of the W-L relationships were estimated by linear regression analysis, using the least-squares method. The degree of association between the variables $\mathrm{W}$ and $\mathrm{L}$ was calculated by the coefficient of determination $\left(\mathrm{R}^{2}\right)$. The conversion factor for gutted to total weight was also calculated by forcing the linear relationships through the co-ordinates origin.

For fish with all data, total, gutted and gonad weight, the condition factor (CF), the gonadosomatic index (GSI) and the hepatosomatic index (HSI) were also calculated, in this way: $\mathrm{CF}_{\mathrm{t}}=\mathrm{W}_{\mathrm{t}} / \mathrm{L}^{3} * 100$ and $\mathrm{CF}_{\mathrm{g}}=\mathrm{W}_{\mathrm{g}} / \mathrm{L}^{3} * 100$ (Fulton, 1902) [33]; $\mathrm{GSI}_{\mathrm{t}}=\mathrm{W}_{\mathrm{gon}} / \mathrm{W}_{\mathrm{t}} * 100$ and $\mathrm{GSI}_{\mathrm{g}}=$ $\mathrm{W}_{\text {gon }} / \mathrm{W}_{\mathrm{g}} * 100 ; \mathrm{HSI}_{\mathrm{t}}=\mathrm{W}_{\text {liv }} / \mathrm{W}_{\mathrm{t}} * 100$ and $\mathrm{HSI}_{\mathrm{g}}=\mathrm{W}_{\text {liv }} / \mathrm{W}_{\mathrm{g}}$ * 100 (West, 1990) [34], where $\mathrm{CF}_{\mathrm{t}}=$ condition factor obtained with total weight, $\mathrm{CF}_{\mathrm{g}}=$ condition factor obtained with gutted weight; $\mathrm{GSI}_{\mathrm{t}}=$ gonadosomatic index obtained with total weight, $\mathrm{GSI}_{\mathrm{g}}=$ gonadosomatic index obtained with gutted weight; $\mathrm{HSI}_{\mathrm{t}}=$ hepatosomatic index obtained with total weight, $\mathrm{HSI}_{\mathrm{g}}=$ hepatosomatic index obtained with gutted weight; $\mathrm{W}_{\mathrm{t}}=$ total weight $(\mathrm{g}), \mathrm{W}_{\mathrm{g}}=$ gutted weight $(\mathrm{g}), \mathrm{L}=$ total length $(\mathrm{cm}), \mathrm{W}_{\text {gon }}=$ gonad weight $(\mathrm{g}), \mathrm{W}_{\text {liv }}=$ liver weight $(\mathrm{g})$. Condition factor, gonadosomatic and hepatosomatic indices were analysed by sex and within each sex the individuals were also split into immature and mature. Females were considered to be immature with less than $38 \mathrm{~cm}$ total length and males were considered immature with less than $26 \mathrm{~cm}$ total length, based on the mean of the $\mathrm{L}_{50}$ calculated for the years from 2006 to 2009 from the individuals obtained with visceras (Costa et al., 2009) [21].

Conversion factors between gutted and total weights were calculated by sex for all fish sampled.

The weight of the viscera was calculated by sex, as a percentage of the total weight. The spawning season was estimated by studying the percentages of maturity stages assigned de visu to each specimen, based on the macroscopic maturity scale key for hake (ICES, 2007) [35] (Table 2) along with the ovary weight and the obtained GSI and HSI.

\section{Results and Discussion}

Although the studied period started in January 2005 and finished in December 2010, to understand the importance of this species along the years, the hake landings and fish auction market price were analysed for the all decade (2000-2010) and are presented in Figure 1.

The annual length distribution of sampled hake landed by the different fishing gears in the studied period is shown in Figure 2.

Total lengths of fish sampled ranged from 7.3 to 93.3 $\mathrm{cm}$, with $49.8 \%$ of the fish belonging to 30 to $50 \mathrm{~cm}$ length. Total length of females ranged from $20.0 \mathrm{~cm}$ (with $44.0 \mathrm{~g}$ weight) in April, to $82.8 \mathrm{~cm}$ (with 5304.0

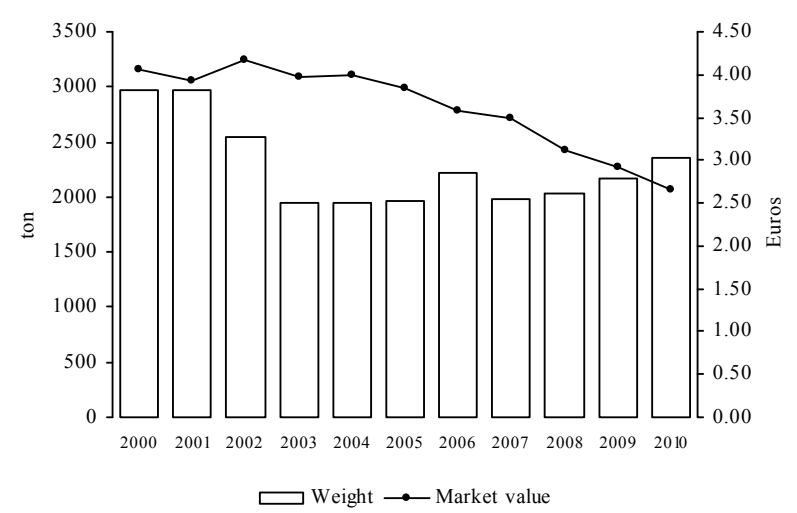

Figure 1. Mean catches and mean market value of hake in the decade 2000-2010. The values correspond to the means of the different fishing gears operating at the twelve ports studied (source: DGPA, 2000 to 2010 [105 - 115]).

Table 1. Number of M. merluccius caught during 2005-2010 in the Portuguese coast.

\begin{tabular}{|c|c|c|c|c|c|c|c|c|c|c|c|c|c|c|}
\hline \multirow{2}{*}{ Year } & \multicolumn{12}{|c|}{ Month } & \multirow{2}{*}{ Total } & \multirow{2}{*}{ Length range $(\mathrm{cm})$} \\
\hline & Jan. & Feb. & Mar. & Apr. & May & Jun. & Jul. & Aug. & Sep. & Oct. & Nov. & Dec. & & \\
\hline 2005 & 21 & 105 & 107 & 466 & 91 & 102 & 121 & 29 & 70 & 117 & 79 & & 1308 & $8.5-71.3$ \\
\hline 2006 & 14 & 100 & 94 & 102 & 105 & 38 & 117 & 86 & 87 & 33 & 68 & & 844 & $8.0-71.1$ \\
\hline 2007 & 86 & 104 & 105 & 136 & 105 & 183 & 58 & 65 & 56 & 57 & 57 & & 1012 & $12.5-93.3$ \\
\hline 2008 & 111 & 79 & 131 & 87 & 94 & 59 & 155 & 33 & 54 & 166 & 66 & 9 & 1044 & $7.3-82.8$ \\
\hline 2009 & 20 & 91 & 198 & 252 & 239 & 55 & 75 & 130 & 221 & 79 & 96 & 39 & 1495 & $7.9-77.5$ \\
\hline 2010 & 107 & 132 & 423 & 208 & 307 & 245 & 171 & 163 & 262 & 246 & 245 & & 2509 & $7.5-78.9$ \\
\hline Total & 359 & 611 & 1058 & 1251 & 941 & 682 & 697 & 506 & 750 & 698 & 611 & 48 & 8212 & $7.3-93.3$ \\
\hline
\end{tabular}


Table 2. Hake macroscopic maturity stages (ICES, 2007).

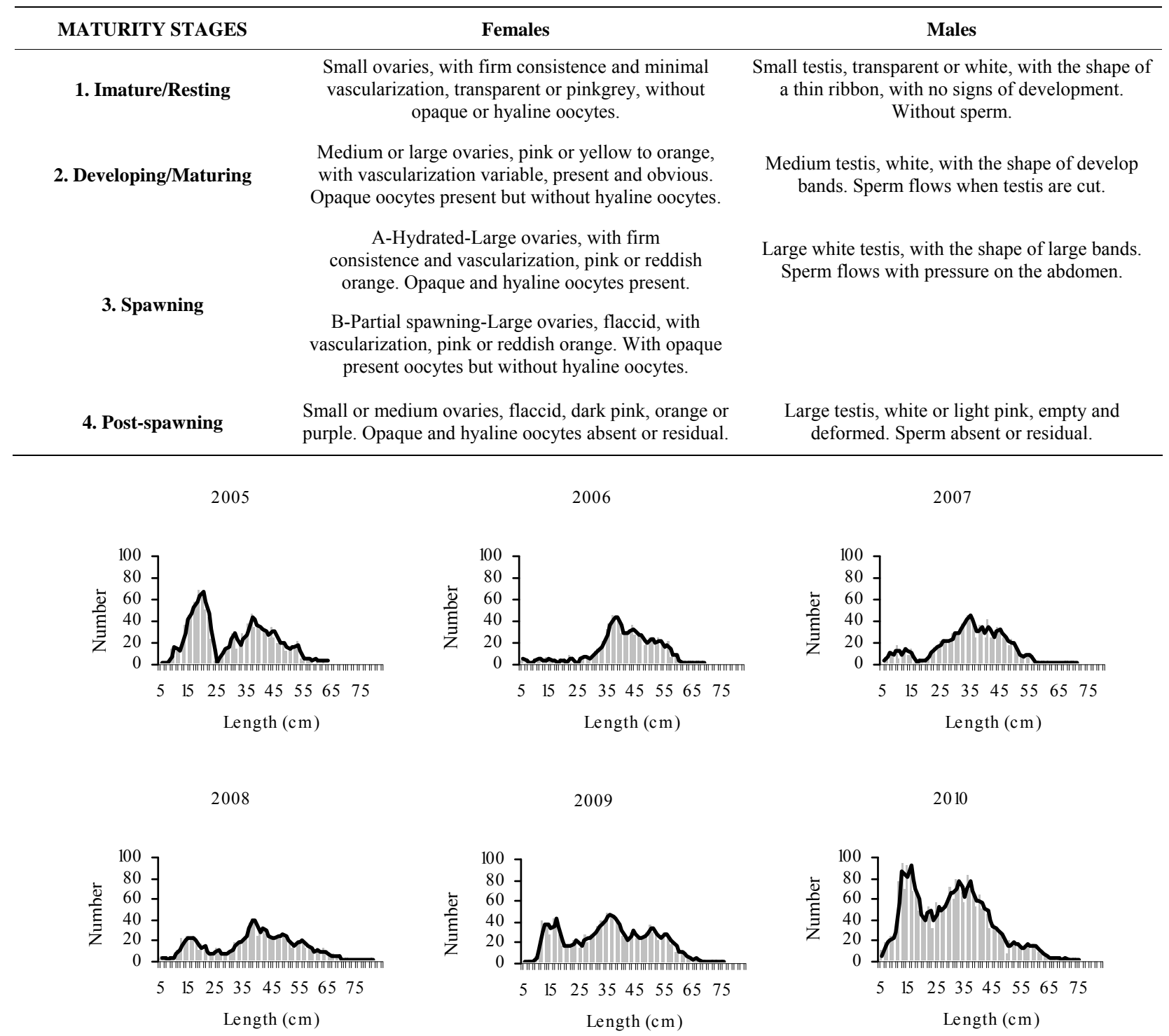

Figure 2. Annual length composition of hake sampled during the period 2005-2010.

$\mathrm{g}$ weight) in July. Total length of males ranged from 20.0 $\mathrm{cm}$ (with $46.0 \mathrm{~g}$ weight) in April to $66.1 \mathrm{~cm}$ (with 2057.9 $\mathrm{g}$ weight) in May. Fish smaller than $25 \mathrm{~cm}$ length, with high numbers in 2005, decreased greatly in the samples of 2006, but from 2007 onwards their abundance raised and in 2010 the number of fish sampled with less than 25 $\mathrm{cm}$ was very high. The number of sampled fish bigger than $55 \mathrm{~cm}$ length was in general low in all the years.

Fish smaller than $20.0 \mathrm{~cm}$ length were not sexed, whatled to a total of 5215 fish macroscopically sexed (3592 females and 1623 males). Individuals whose sex assign ment presented doubts were not considered. Most of the fish sexed belonged to length range $20-30 \mathrm{~cm}$ $(86.8 \%)$ and $30-40 \mathrm{~cm}(91.5 \%)$, showing a sex ratio close to 1:1 (Figure 3). In length classes bigger than 40

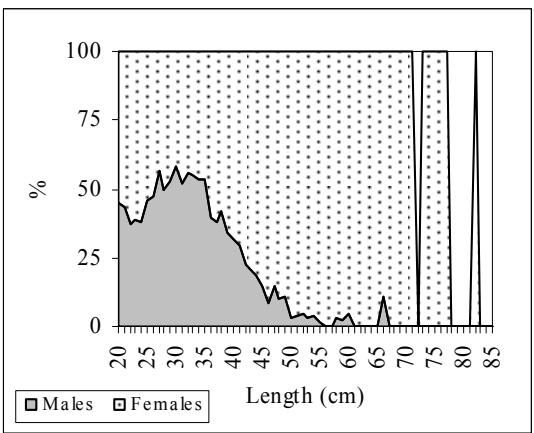

Figure 3. Sex ratio for hake in the Portuguese coast in the period 2005-2010.

$\mathrm{cm}$ the proportion of fish sexed was smaller but there was a high predominance of females, in particular among 
the individuals over $50 \mathrm{~cm}$ length (97.3\%).

\subsection{Length-Weight Relationships}

The relationships between total length and total weight were determined for both sexes by month in a total of 5471 specimens (1889 males and 3582 females). The es- timated parameters of the total length-total weight relationships, the number of fish, length and weight ranges and the correlation coeficients are presented in Table 3 (years are pooled by month).

The same parameters were estimated for the total length-gutted weight relationships, with a total of 6657 fish, which are presented in Table 4. In this table, where

Table 3. Monthly total length-total weight relationships for hake in the Portuguese coast for the period 2005 -2010 (years are pooled by month).

\begin{tabular}{|c|c|c|c|c|c|c|c|}
\hline Month & Sex & Function & $\mathrm{N}$ & $\mathrm{R}^{2}(\%)$ & $\mathrm{SE}(b)$ & Length range $(\mathrm{cm})$ & Weight range (g) \\
\hline \multirow{3}{*}{ January } & Males & $\mathrm{W}_{\mathrm{t}}=0.0039 \mathrm{~L}^{3.153}$ & 118 & 97.41 & 0.048 & $26.2-49.9$ & $127.0-760.0$ \\
\hline & Females & $\mathrm{W}_{\mathrm{t}}=0.0076 \mathrm{~L}^{3.005}$ & 151 & 95.84 & 0.051 & $24.5-73.0$ & $107.0-2623.0$ \\
\hline & Sexes combined & $\mathrm{W}_{\mathrm{t}}=0.0040 \mathrm{~L}^{3.164}$ & 269 & 96.04 & 0.039 & $24.5-73.0$ & $107.0-2623.0$ \\
\hline \multirow{3}{*}{ February } & Males & $\mathrm{W}_{\mathrm{t}}=0.0072 \mathrm{~L}^{2.983}$ & 170 & 94.50 & 0.056 & $20.3-45.3$ & $43.8-631.0$ \\
\hline & Females & $\mathrm{W}_{\mathrm{t}}=0.0040 \mathrm{~L}^{3.166}$ & 229 & 97.57 & 0.033 & $20.3-77.0$ & $48.5-3280.0$ \\
\hline & Sexes combined & $\mathrm{W}_{\mathrm{t}}=0.0036 \mathrm{~L}^{3.193}$ & 399 & 97.36 & 0.026 & $20.3-77.0$ & $43.8-3280.0$ \\
\hline \multirow{3}{*}{ March } & Males & $\mathrm{W}_{\mathrm{t}}=0.00449 \mathrm{~L}^{3.122}$ & 251 & 98.23 & 0.027 & $20.0-52.0$ & $47.1-1035.6$ \\
\hline & Females & $\mathrm{W}_{\mathrm{t}}=0.0039 \mathrm{~L}^{3.164}$ & 379 & 98.78 & 0.018 & $20.0-70.1$ & $44.7-2816.0$ \\
\hline & Sexes combined & $\mathrm{W}_{\mathrm{t}}=0.0037 \mathrm{~L}^{3.178}$ & 630 & 98.78 & 0.014 & $20.0-70.1$ & $44.7-2816.0$ \\
\hline \multirow{2}{*}{ April } & Males & $\mathrm{W}_{\mathrm{t}}=0.0037 \mathrm{~L}^{3.171}$ & 312 & 98.70 & 0.021 & $20.0-53.2$ & $44.0-1022.0$ \\
\hline & Sexes combined & $\mathrm{W}_{\mathrm{t}}=0.0034 \mathrm{~L}^{3.196}$ & 995 & 99.19 & 0.009 & $20.0-77.5$ & $40.0-3236.0$ \\
\hline \multirow{3}{*}{ May } & Males & $\mathrm{W}_{\mathrm{t}}=0.0049 \mathrm{~L}^{3.093}$ & 209 & 98.96 & 0.022 & $20.0-66.1$ & $45.8-2057.9$ \\
\hline & Females & $\mathrm{W}_{\mathrm{t}}=0.0051 \mathrm{~L}^{3.092}$ & 411 & 98.74 & 0.017 & $20.0-74.0$ & $44.4-3148.0$ \\
\hline & Sexes combined & $\mathrm{W}_{\mathrm{t}}=0.0046 \mathrm{~L}^{3.113}$ & 620 & 99.02 & 0.012 & $20.0-74.0$ & $44.4-3148.0$ \\
\hline \multirow{3}{*}{ June } & Males & $\mathrm{W}_{\mathrm{t}}=0.0058 \mathrm{~L}^{3.031}$ & 142 & 99.13 & 0.024 & $20.0-70.4$ & $44.0-2172.0$ \\
\hline & Females & $\mathrm{W}_{\mathrm{t}}=0.0040 \mathrm{~L}^{3.161}$ & 232 & 98.55 & 0.025 & $20.3-66.8$ & $45.8-2278.0$ \\
\hline & Sexes combined & $\mathrm{W}_{\mathrm{t}}=0.0040 \mathrm{~L}^{3.153}$ & 374 & 98.86 & 0.018 & $20.0-70.4$ & $44.0-2278.0$ \\
\hline \multirow{3}{*}{ July } & Males & $\mathrm{W}_{\mathrm{t}}=0.0049 \mathrm{~L}^{3.088}$ & 149 & 98.26 & 0.021 & $20.1-50.8$ & $48.0-860.0$ \\
\hline & Females & $\mathrm{W}_{\mathrm{t}}=0.0041 \mathrm{~L}^{3.165}$ & 389 & 98.79 & 0.018 & $20.0-82.8$ & $45.0-5304.0$ \\
\hline & Sexes combined & $\mathrm{W}_{\mathrm{t}}=0.0035 \mathrm{~L}^{3.200}$ & 538 & 98.88 & 0.015 & $20.0-82.8$ & $45.0-5304.0$ \\
\hline August & Sexes combined & $\mathrm{W}_{\mathrm{t}}=0.0052 \mathrm{~L}^{3.099}$ & 380 & 98.07 & 0.022 & $20.7-76.7$ & $52.0-3151.0$ \\
\hline \multirow{3}{*}{ September } & Males & $\mathrm{W}_{\mathrm{t}}=0.0043 \mathrm{~L}^{3.141}$ & 140 & 98.01 & 0.038 & $20.6-46.7$ & $57.6-700.0$ \\
\hline & Females & $\mathrm{W}_{\mathrm{t}}=0.0052 \mathrm{~L}^{3.096}$ & 330 & 98.45 & 0.021 & $20.1-67.8$ & $44.3-2358.0$ \\
\hline & Sexes combined & $\mathrm{W}_{\mathrm{t}}=0.0046 \mathrm{~L}^{3.131}$ & 470 & 98.49 & 0.018 & $20.1-67.8$ & $44.3-2358.0$ \\
\hline \multirow{3}{*}{ October } & Males & $\mathrm{W}_{\mathrm{t}}=0.0034 \mathrm{~L}^{3.197}$ & 94 & 97.74 & 0.051 & $20.1-49.0$ & $54.6-1050.0$ \\
\hline & Females & $\mathrm{W}_{\mathrm{t}}=0.00376 \mathrm{~L}^{3.190}$ & 278 & 97.93 & 0.028 & $20.0-69.8$ & $42.9-2252.0$ \\
\hline & Sexes combined & $\mathrm{W}_{\mathrm{t}}=0.0032 \mathrm{~L}^{3.223}$ & 372 & 98.20 & 0.023 & $20.0-69.8$ & $42.9-2252.0$ \\
\hline \multirow{3}{*}{ November } & Males & $\mathrm{W}_{\mathrm{t}}=0.0061 \mathrm{~L}^{3.036}$ & 163 & 97.38 & 0.039 & $21.0-54.7$ & $59.9-1034.0$ \\
\hline & Females & $\mathrm{W}_{\mathrm{t}}=0.0058 \mathrm{~L}^{3.065}$ & 222 & 97.75 & 0.031 & $20.4-77.0$ & $66.0-3332.0$ \\
\hline & Sexes combined & $\mathrm{W}_{\mathrm{t}}=0.0052 \mathrm{~L}^{3.091}$ & 385 & 97.64 & 0.025 & $20.4-77.0$ & $59.9-3332.0$ \\
\hline \multirow{3}{*}{ December } & Males & $\mathrm{W}_{\mathrm{t}}=0.0016 \mathrm{~L}^{3.418}$ & 32 & 92.79 & 0.174 & $24.5-39.2$ & $102.5-438.6$ \\
\hline & Females & & & & & & \\
\hline & Sexes combined & $\mathrm{W}_{\mathrm{t}}=0.0007 \mathrm{~L}^{3.665}$ & 39 & 93.72 & 0.156 & $24.5-39.2$ & $102.5-500.9$ \\
\hline
\end{tabular}


Table 4. Monthly total length-gutted weight relationships for hake in the Portuguese coast for the perid 2005-2010 (years are pooled by month).

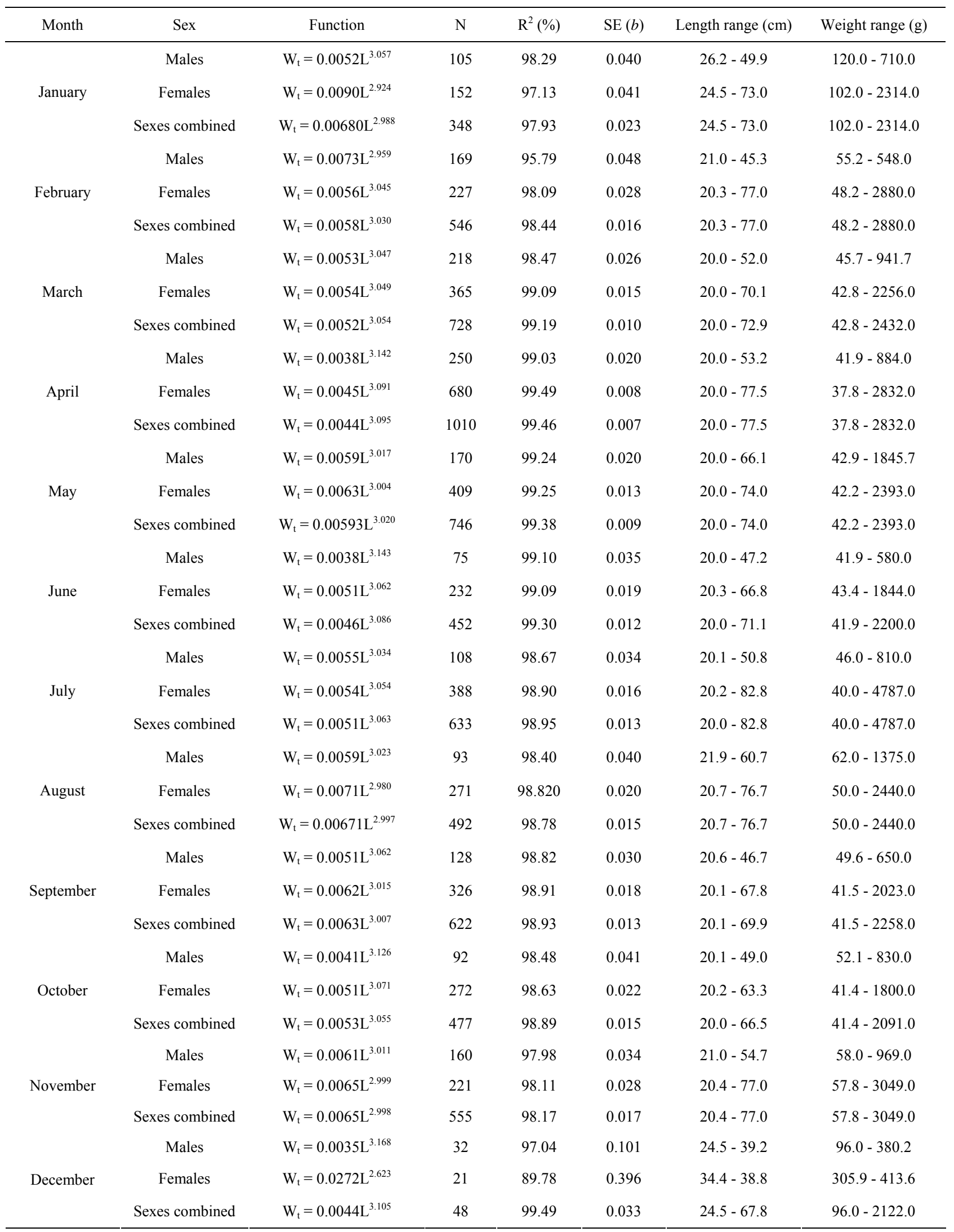


years are pooled by month, the values of sexes combined were obtained not only with the sexed fish but also with the adult fish (over $20 \mathrm{~cm}$ length) landed already gutted.

The total length and weights relationships for the total individuals sampled and by sexes are shown in Tables 5 and 6.

Length-weight relationships were statistically compared to determine whether there were differences in growth rate between males and females, considering the same length ranges for comparison. The results seem to indicate that the annual growth is similar for males and females (Table 7).

In Table 8 are shown the monthly relationships between total and gutted weights for males, females and sexes combined, the length and weight ranges, number of fish sampled and the correlation coefficient obtained (years are pooled by month).

Grouping together the monthly values of total and gutted weights the relationships found are: $\mathrm{W}_{\mathrm{t}}=7.0261+$ $0.892 \mathrm{~W}_{\mathrm{g}}$ for males, $\mathrm{W}_{\mathrm{t}}=16.3313+0.845 \mathrm{~W}_{\mathrm{g}}$ for females and $\mathrm{W}_{\mathrm{t}}=15.8112+0.848 \mathrm{~W}_{\mathrm{g}}$ for sexes combined.

Considering the same length ranges, total weight- gutted weight relationships were also statistically compared for both sexes, showing that the annual growth is different for total weight and gutted weight (Table 7).

According to these results the growth rates of males and females are similar for both sexes although higher when calculated with total weight than with gutted weight.

Conversion factors between gutted and total weights are presented in Table 9 .

Grouping together the monthly conversion factors between gutted and total weights the values obtained are: 1.0980 for males, 1.1585 for females and 1.1524 for sexes combined.

As seen in the Figure 4, and particularly in females, in the length classes over $30 \mathrm{~cm}$ viscera represent more than $10 \%$ of the total weight and more than $15 \%$ in length classes over $60 \mathrm{~cm}$. Considering the mean weight of all length classes viscera account for $13.28 \%$ of total weight. The monthly evolution of the visceras weights show for both sexes an increasing trend from January to August, then decreasing until November rising again in December, particularly in females.

\subsection{Somatic Condition}

Condition factor (Fulton factor) was calculated with total weight (TW) and gutted weight (GW). Mature females $(\geq 38 \mathrm{~cm})$ showed always higher values than immature females $(<38 \mathrm{~cm})$ during the entire period, with a similar but smoother oscillation (Figure 5).

Both immature $(<26 \mathrm{~cm})$ and mature males $(\geq 26 \mathrm{~cm})$ didn't show high variations of this index along the year.

The gonadosomatic index, obtained either with the total weight (TW) or the gutted weight (GW), showed the same general pattern for males and females along the year (Figure 6). The values of both indices for females were about 3 times higher of the values of the same indices for males. Immature and mature females showed an opposite variation of GSI during the first semester but in the second half of the year the variation was similar for all the females. Due to the lack of samples this comparison could not be done for males.

The monthly evolution of the hepatosomatic index obtained with the total weight $\left(\mathrm{HSI}_{\mathrm{t}}\right)$ and the gutted weight $\left(\mathrm{HSI}_{\mathrm{g}}\right)$ was similar for mature and immature fish, with the $\mathrm{HSI}_{\mathrm{g}}$ values slightly higher (Figure 7). Females' maximum values of these indices were found in the beginning of the 4 th quarter (October) while mature males $(\geq 26 \mathrm{~cm})$ showed a sharp increase in June.

For both sexes the Pearson coefficient (r) shows stronger correlations (Cohen, 1988) [36] between GSI and CF or HSI when using gutted weight (Table 10). With total weight those relationships are in general medium and between HSI and CF they are weak, either for males or females.

Table 5. Total length-total weight relationships for hake in the Portuguese coast for the period 2005-2010.

\begin{tabular}{ccccccc}
\hline & $\mathrm{N}$ & $\mathrm{W} / \mathrm{L}$ & $\mathrm{R}^{2}(\%)$ & SE $(b)$ & Length range $(\mathrm{cm})$ & $\mathrm{Weight}$ range $(\mathrm{g})$ \\
\hline Males & 1889 & $\mathrm{~W}_{\mathrm{t}}=0.0043 \mathrm{~L}^{3.127}$ & 98.43 & 0.055 & $20.0-66.1$ & $43.8-1400.0$ \\
Females & 3582 & $\mathrm{~W}_{\mathrm{t}}=0.0042 \mathrm{~L}^{3.150}$ & 98.58 & 0.029 & $20.0-82.8$ \\
Sexes combined & 5471 & $\mathrm{~W}_{\mathrm{t}}=0.0038 \mathrm{~L}^{3.172}$ & 98.69 & 0.022 & $20.0-82.8$ \\
\hline
\end{tabular}

Table 6. Total length-gutted weight relationships for hake in the Portuguese coast for the period 2005-2010.

\begin{tabular}{|c|c|c|c|c|c|c|}
\hline & $\mathrm{N}$ & $\mathrm{W} / \mathrm{L}$ & $\mathrm{R}^{2}(\%)$ & $\mathrm{SE}(b)$ & Length range $(\mathrm{cm})$ & Weight range (g) \\
\hline Maless & 1600 & $\mathrm{~W}_{\mathrm{t}}=0.0047 \mathrm{~L}^{3.082}$ & 98.86 & 0.060 & $20.0-66.1$ & $41.9-1845.7$ \\
\hline Females & 3550 & $\mathrm{~W}_{\mathrm{t}}=0.0054 \mathrm{~L}^{3.049}$ & 99.03 & 0.056 & $20.0-82.8$ & $37.8-4787.0$ \\
\hline Sexes combined & 6657 & $\mathrm{~W}_{\mathrm{t}}=0.0052 \mathrm{~L}^{3.059}$ & 99.11 & 0.043 & $20.0-82.8$ & $37.8-1845.7$ \\
\hline
\end{tabular}


Table 7. Statitical analysis of the growth rate of Portuguese hake.

\begin{tabular}{|c|c|c|c|c|}
\hline \multicolumn{5}{|l|}{ Call: } \\
\hline \multicolumn{5}{|c|}{$\operatorname{lm}($ formula $=\log ($ weight $) \sim \log ($ length $) *$ type. weight, data $=$ data $)$} \\
\hline \multicolumn{5}{|l|}{ Residuals: } \\
\hline Min & 1Q & Median & $3 \mathrm{Q}$ & Max \\
\hline-0.145038 & -0.031178 & 0.002016 & 0.031580 & 0.090341 \\
\hline \multicolumn{5}{|l|}{ Coefficients: } \\
\hline \multicolumn{5}{|c|}{ Estimate Std. Error $\mathrm{t}$ value $\operatorname{Pr}(>|\mathrm{t}|)$} \\
\hline (Intercept) & -4.99395 & 0.06133 & -81433 & $<2 \mathrm{e}-16^{* * *}$ \\
\hline $\log ($ length) & 2.99168 & 0.01686 & 177482 & $<2 \mathrm{e}-16^{* * *}$ \\
\hline type. totweight & -0.17133 & 0.08673 & -1975 & 0.05001 \\
\hline $\begin{array}{l}\log (\text { length): } \\
\text { type. totweight }\end{array}$ & 0.07432 & 0.02384 & 3118 & $0.00218^{* *}$ \\
\hline Signif. codes: & $0^{\prime * * * 1}$ & $0.001^{\prime * * \prime}$ & $0.01^{\prime * 1}$ & 0.05 '.' $0.1{ }^{\prime \prime}$ \\
\hline \multicolumn{5}{|c|}{ Residual standard error: 0.04659 on 154 degrees of freedom } \\
\hline \multicolumn{5}{|c|}{ Multiple R-squared: 0.9976, } \\
\hline F-statistic: 2.15 & -04 on 3 and & $154 \mathrm{DF}$ & $p$-value & $<2.2 \mathrm{e}^{-}-16$ \\
\hline
\end{tabular}

\subsection{Spawning Season}

The annual evolution of the maturity stages is a good indicator of the spawning period of a species.

The analysis by sex of the proportion of each maturity stage along the year (Figure 8) shows that immature females were present in higher proportions than immature males in every month. In the mature stages (2, 3 and 4$)$ males were in general present at higher proportions, except for maturity stage 3 . The months with the highest proportion of mature stages were May for females (74\%) and November for males (94\%). Considering both sexes May showed the highest proportion of mature stages (76\%).

Another indicator of the spawning season is the monthly evolution of the ovary weight (Figure 9).

In this graphic the 4 peaks of higher ovaries weights (averages) are signalised (sp.) and interpreted as "spawning peaks" and the ascending lines are considered as following recovering periods. Although 2727 ovaries were weighted, the low values observed in December and January are probably due to an insufficient number of individuals sampled (7 and 123, respectively), while in the rest of the year a mean of 260 ovaries were weighted per month.

According to the length class, females spawn mainly three times per year, in January-March, May-June and August, as shown in Table 11. These observations seem to indicate that the start of the spawning is independent of fish length, since the spawning peaks occur at the same time for all the fish lengths. The ascending lines shown in the previous figure in October, November and
December may represent only false spawning peaks, due to the small number of individuals analysed in those months.

Another fact that can be observed is the increase of the weights of the ovaries with length, which can be explained since normally the gonads are bigger on bigger exemplars.

\section{Discussion}

One of the most important and exploited fish species in western demersal fisheries is the european hake (Merluccius merluccius L., 1758) (Casey and Pereiro, 1995) [37], not only due to its high abundance and large distribution but also because of its role in the food chain. Since 1978 the ICES Working Group on the Assessment of Southern Shelf Demersal Stocks (WGSSDS) distinguishes two hake stocks for assessment purposes: the northern stock and the southern stock (ICES, 1979) [38]. Both stocks are outside safe biological limits and EU has developed in 2006 a recovery plan for the southern stock of this species (EU, 2011) [39]. Taking this into account, the administration authorities need cientific advice to ensure the sustainable management of those species, in order to protect the spawning stock. Therefore, in particular during the spawning season, management measures must be taken, which may consist of seasonal bans, the reduction of fishing effort and the update of the estimation of length at first maturity $\left(\mathrm{L}_{50}\right)$, since this parameter can change as a result of the fishing intensity or exploitation pattern (BIOSDEF, 1998) [40]. One of the most important management measures for a certain species is the establishment of its minimum landing size, along with the obligation of discarding to the sea all the individuals with smaller sizes. In order to have a biological meaning this minimum size must allow the individuals to reach the size of reproduction, but it must also take into account the characteristics of the fishing gear that captures that species, in other words, its selectivity. The Council Regulation (EC) No. 850/98 of 30 March 1998 established for the european hake the minimum landing size of $27 \mathrm{~cm}$.

Due to the economical importance of hake there are abundante studies about several subjects, such as, biology, maturity, fecundity, reproduction, distribution and growth, not only on the species Merluccius merluccius (Biagi et al., 1995 [41]; de Pontual et al., 2006 [42]; Domínguez-Petit et al., 2008 [43]; El Habouz et al., 2011 [44]; Korta et al., 2010 [45]; Murua and Motos, 2006 [46]; Murua et al., 1998 [47]; Piñeiro and Sainza, 2003 [48]; Velasco and Olaso, 1998 [49], among others) as on the other species of Merluccius (e.g. Balbontin and Fischer, 1981 [50]; Fernández-Peralta et al., 2011 [51]; Honji et al., 2006 [52]; Relini et al., 2002 [53]). Al- 
though in Portugal there has been a directed trawl fishery for white hake for many years and substantial quantities are catch with different fishing gears, biological investigations have been rather limited. Thereby, in the present study some parameters are presented and discussed in order to clarify some characteristics related to the biology of Merluccius merluccius that inhabits the waters along the portuguese coast.

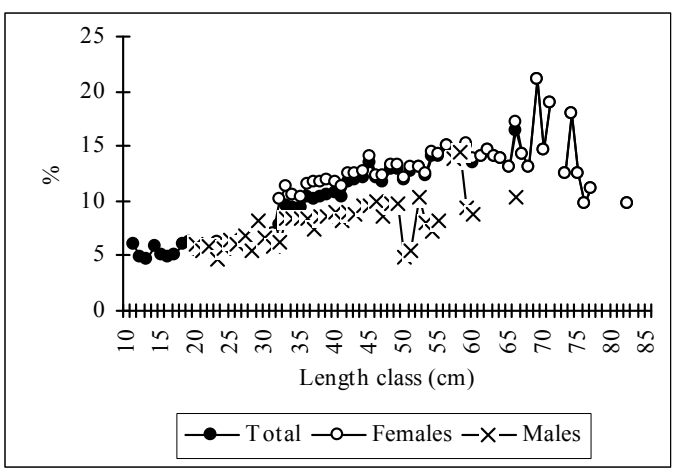

Regarding the length distribution of hake along the years, fish smaller than $25 \mathrm{~cm}$, present in 2005, almost desappeared in 2006, increasing again in 2007, what might be explained by the fluctuations of the recruitment indices in those years. The oscillations in hake catches are not a portuguese problem in particular. Since the 1960s (FAO, 2010) [54] European hake catches have been decreasing and the commercial viability of aqua

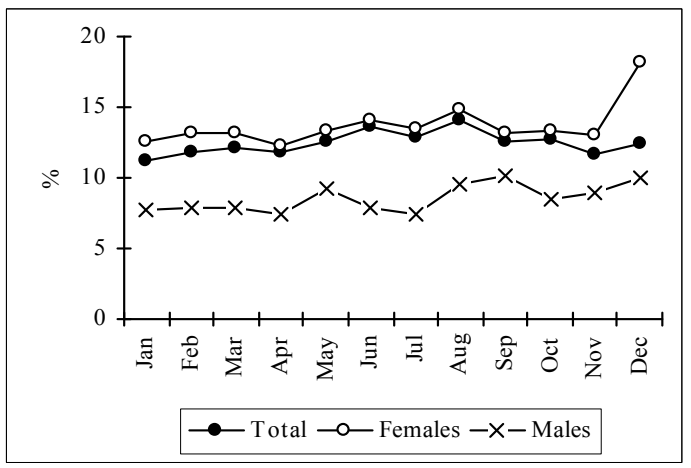

Figure 4. Percentage of viscera weight on the total weight by length class and by month of hake in the Portuguese Coast in the period 2005-2010. Females-length classes 73, 75, 76 e $82 \mathrm{~cm}$ with only 1 fish. Males-length classes 55, 57, 59 e 66 cm with only 1 fish.
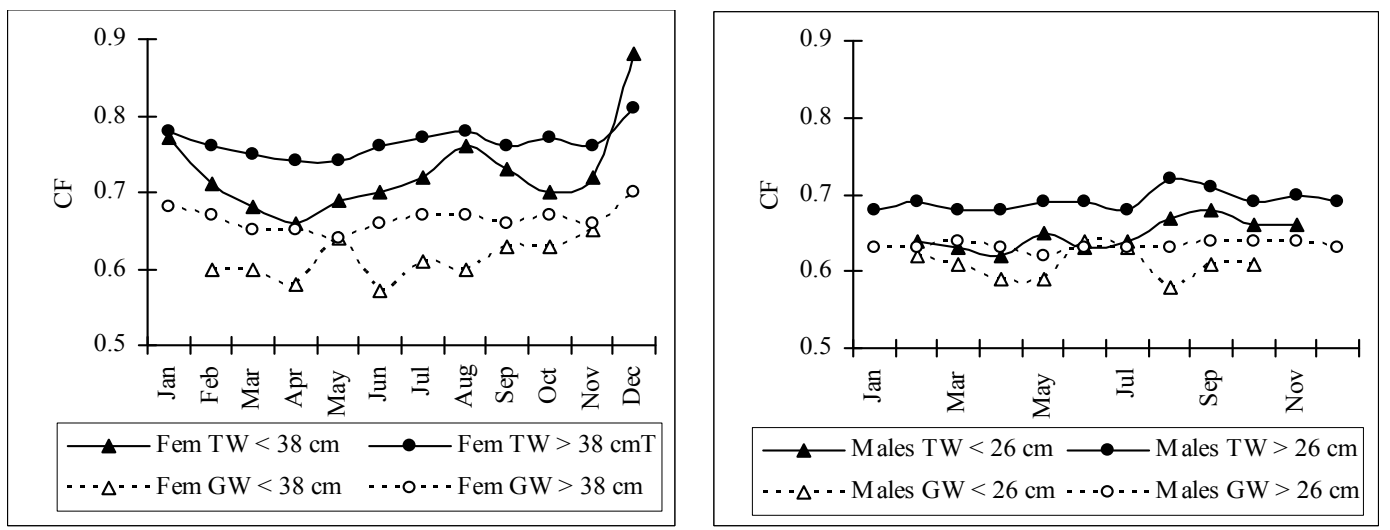

Figure 5. Condition factor monthly evolution using the total and gutted weight for hake in the Portuguese coast in the period 2005-2010.
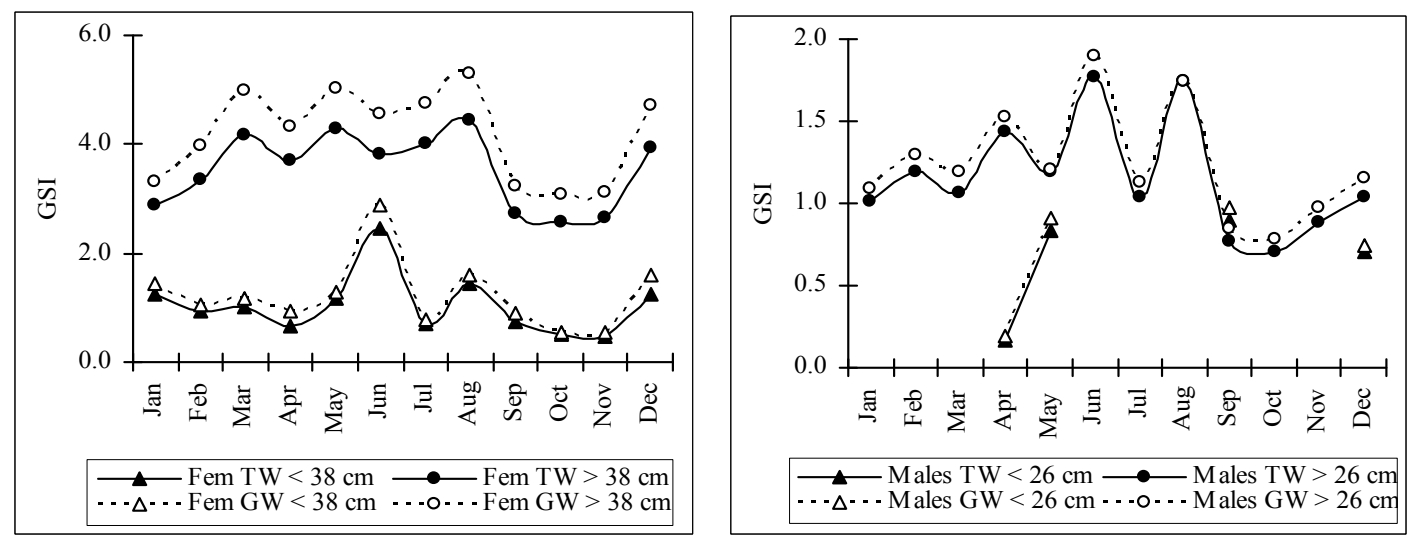

Figure 6. Gonadosomatic index monthly evolution calculated using the total and gutted weight for hake in the Portuguese Coast in the period 2005-2010. 
Table 8. Monthly total weight $\left(W_{t}\right)$-gutted weight $\left(W_{g}\right)$ relationships for hake in the Portuguese coast for the period 20052010 (years are pooled by month).

\begin{tabular}{|c|c|c|c|c|c|c|c|}
\hline Month & Sex & Function & $\mathrm{N}$ & R2 (\%) & $\mathrm{W}_{\mathrm{t}}$ range $(\mathrm{g})$ & $\mathrm{W}_{\mathrm{g}}$ range $(\mathrm{g})$ & Length range $(\mathrm{cm})$ \\
\hline \multirow{2}{*}{ January } & Males & $\mathrm{W}_{\mathrm{t}}=10.8579+0.890 \mathrm{Wg}$ & 105 & 98.93 & $127.00-760.00$ & $120.00-710.00$ & $26.2-49.9$ \\
\hline & Sexes combined & $\mathrm{W}_{\mathrm{t}}=14.4329+0.860 \mathrm{Wg}$ & 269 & 98.96 & $107.00-2623.00$ & $102.00-2314.00$ & $24.5-73.0$ \\
\hline \multirow{3}{*}{ February } & Males & $\mathrm{W}_{\mathrm{t}}=7.7719+0.895 \mathrm{Wg}$ & 168 & 96.81 & $57.58-631.00$ & $55.16-548.00$ & $21.0-45.3$ \\
\hline & Females & $\mathrm{W}_{\mathrm{t}}=32.2629+0.820 \mathrm{Wg}$ & 227 & 98.54 & $48.45-3280.00$ & $48.20-2880.00$ & $20.3-77.0$ \\
\hline & Sexes combined & $\mathrm{W}_{\mathrm{t}}=25.8547+0.833 \mathrm{Wg}$ & 395 & 99.21 & $48.45-3280.00$ & $48.20-2880.00$ & $20.3-77.0$ \\
\hline \multirow[b]{2}{*}{ March } & Males & $\mathrm{W}_{\mathrm{t}}=5.8765+0.902 \mathrm{Wg}$ & 218 & 98.71 & $49.31-1035.60$ & $45.70-941.70$ & $20.0-52.0$ \\
\hline & Females & $\mathrm{W}_{\mathrm{t}}=23.3082+0.837 \mathrm{Wg}$ & 367 & 97.66 & $44.65-2816.00$ & $42.79-2256.00$ & $20.0-70.1$ \\
\hline \multirow{3}{*}{ April } & Males & $\mathrm{W}_{\mathrm{t}}=4.1006+0.905 \mathrm{Wg}$ & 251 & 99.45 & $44.10-1022.00$ & $41.90-884.00$ & $20.0-53.21$ \\
\hline & Females & $\mathrm{W}_{\mathrm{t}}=13.8052+0.854 \mathrm{Wg}$ & 680 & 99.26 & $40.00-3236.00$ & $37.80-2832.00$ & $20.0-77.5$ \\
\hline & Sexes combined & $\mathrm{W}_{\mathrm{t}}=11.5994+0.857 \mathrm{Wg}$ & 1073 & 99.40 & $6.30-3236.00$ & $6.00-2832.00$ & $11.0-77.5$ \\
\hline \multirow{3}{*}{ May } & Males & $\mathrm{W}_{\mathrm{t}}=14.3193+0.869 \mathrm{Wg}$ & 170 & 99.02 & $45.80-2057.90$ & $42.90-1845.70$ & $20.0-66.1$ \\
\hline & Females & $\mathrm{W}_{\mathrm{t}}=24.0047+0.841 \mathrm{Wg}$ & 409 & 98.90 & $44.38-3148.00$ & $42.20-2393.00$ & $20.0-74.0$ \\
\hline & Sexes combined & $\mathrm{W}_{\mathrm{t}}=21.0809+0.844 \mathrm{Wg}$ & 618 & 99.12 & $43.00-3148.00$ & $41.00-2393.00$ & $18.3-74.0$ \\
\hline \multirow{3}{*}{ June } & Males & $\mathrm{W}_{\mathrm{t}}=0.8239+0.917 \mathrm{Wg}$ & 75 & 99.39 & $44.00-640.00$ & $41.90-580.00$ & $20.0-47.2$ \\
\hline & Females & $\mathrm{W}_{\mathrm{t}}=11.7155+0.836 \mathrm{Wg}$ & 234 & 98.63 & $45.82-2278.00$ & $43.43-1844.00$ & $20.3-66.8$ \\
\hline & Sexes combined & $\mathrm{W}_{\mathrm{t}}=15.3765+0.839 \mathrm{Wg}$ & 344 & 99.01 & $44.00-2278.00$ & $41.90-1844.00$ & $20.0-66.8$ \\
\hline \multirow[t]{2}{*}{ July } & Females & $\mathrm{W}_{\mathrm{t}}=3.4795+0.861 \mathrm{Wg}$ & 388 & 99.15 & $45.00-5304.00$ & $40.00-4787.00$ & $20.0-82.8$ \\
\hline & Sexes combined & $\mathrm{W}_{\mathrm{t}}=7.4754+0.859 \mathrm{Wg}$ & 530 & 99.27 & $45.00-5304.00$ & $40.00-4787.00$ & $19.5-82.8$ \\
\hline \multirow{3}{*}{ August } & Males & $\mathrm{W}_{\mathrm{t}}=-4.9365+0.916 \mathrm{Wg}$ & 93 & 99.20 & $64.00-1504.00$ & $62.00-1375.00$ & $21.9-60.7$ \\
\hline & Females & $\mathrm{W}_{\mathrm{t}}=22.4510+0.828 \mathrm{Wg}$ & 271 & 98.44 & $52.00-3151.00$ & $50.00-2440.00$ & $20.7-76.7$ \\
\hline & Sexes combined & $\mathrm{W}_{\mathrm{t}}=17.1429+0.837 \mathrm{Wg}$ & 376 & 98.79 & $52.00-3151.00$ & $50.00-2440.00$ & $20.7-76.7$ \\
\hline \multirow{3}{*}{ September } & Males & $\mathrm{W}_{\mathrm{t}}=10.8442+0.859 \mathrm{Wg}$ & 128 & 98.16 & $57.60-700.00$ & $49.57-650.00$ & $20.6-46.7$ \\
\hline & Females & $\mathrm{W}_{\mathrm{t}}=12.3124+0.848 \mathrm{Wg}$ & 326 & 99.10 & $44.33-2358.00$ & $41.47-2023.00$ & $20.1-67.8$ \\
\hline & Sexes combined & $\mathrm{W}_{\mathrm{t}}=12.3786+0.848 \mathrm{Wg}$ & 461 & 99.11 & $44.33-2358.00$ & $41.47-2023.00$ & $20.1-67.8$ \\
\hline \multirow{3}{*}{ October } & Males & $\mathrm{W}_{\mathrm{t}}=19.0749+0.848 \mathrm{Wg}$ & 92 & 98.78 & $54.62-1050.00$ & $52.10-830.00$ & $20.1-49.0$ \\
\hline & Females & $\mathrm{W}_{\mathrm{t}}=25.0761+0.833 \mathrm{Wg}$ & 272 & 98.40 & $42.90-2252.00$ & $41.40-1800.00$ & $20.0-63.3$ \\
\hline & Sexes combined & $\mathrm{W}_{\mathrm{t}}=27.5351+0.834 \mathrm{Wg}$ & 365 & 98.67 & $42.90-2252.00$ & $41.40-1800.00$ & $20.0-63.3$ \\
\hline \multirow{3}{*}{ November } & Males & $\mathrm{W}_{\mathrm{t}}=1.5425+0.909 \mathrm{Wg}$ & 159 & 98.45 & $59.90-1034.00$ & $58.00-969.00$ & $21.0-54.7$ \\
\hline & Females & $\mathrm{W}_{\mathrm{t}}=2.0613+0.867 \mathrm{Wg}$ & 221 & 99.05 & $66.00-3332.00$ & $57.80-3049.00$ & $20.4-77.0$ \\
\hline & Sexes combined & $\mathrm{W}_{\mathrm{t}}=11.1763+0.864 \mathrm{Wg}$ & 381 & 98.95 & $59.90-3332.00$ & $57.80-3049.00$ & $20.4-77.0$ \\
\hline \multirow{3}{*}{ December } & Males & $\mathrm{W}_{\mathrm{t}}=25.0887+0.786 \mathrm{Wg}$ & 32 & 95.49 & $102.50-438.60$ & $96.00-380.20$ & $24.5-39.2$ \\
\hline & Females & $\mathrm{W}_{\mathrm{t}}=-3.6363+0.827 \mathrm{Wg}$ & 7 & 63.84 & $386.00-500.90$ & $305.90-413.60$ & $34.4-38.8$ \\
\hline & Sexes combined & $\mathrm{W}_{\mathrm{t}}=30.0361+0.759 \mathrm{Wg}$ & 39 & 96.17 & $102.50-500.90$ & $96.00-413.60$ & $24.5-39.2$ \\
\hline
\end{tabular}



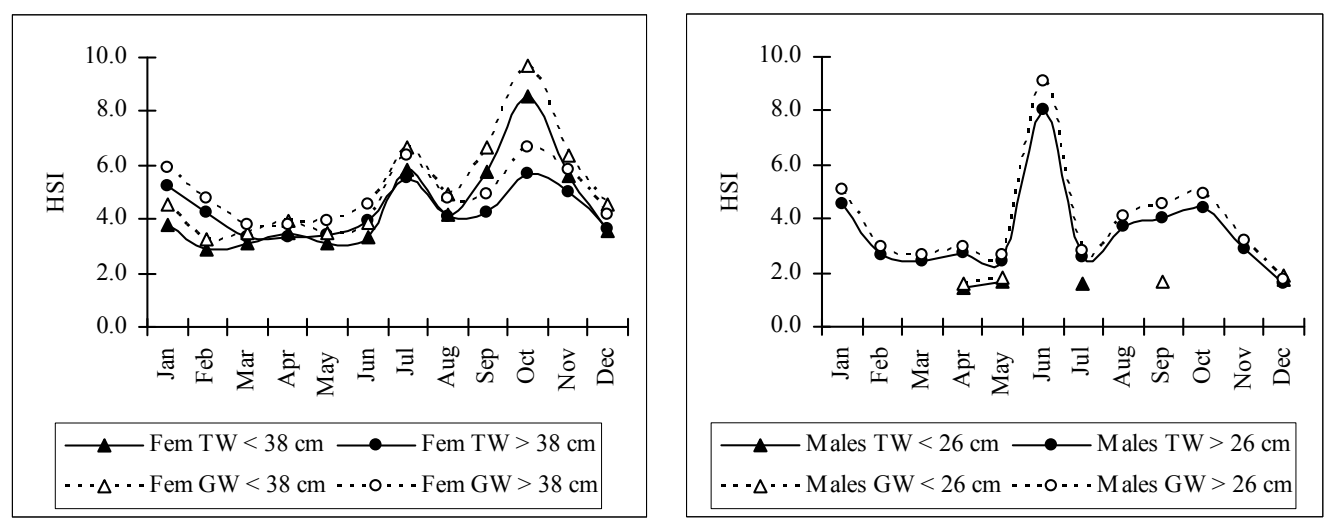

Figure 7. Hepatosomatic index monthly evolution calculated using the total and gutted weight for hake in the Portuguese Coast in the period 2005-2010.
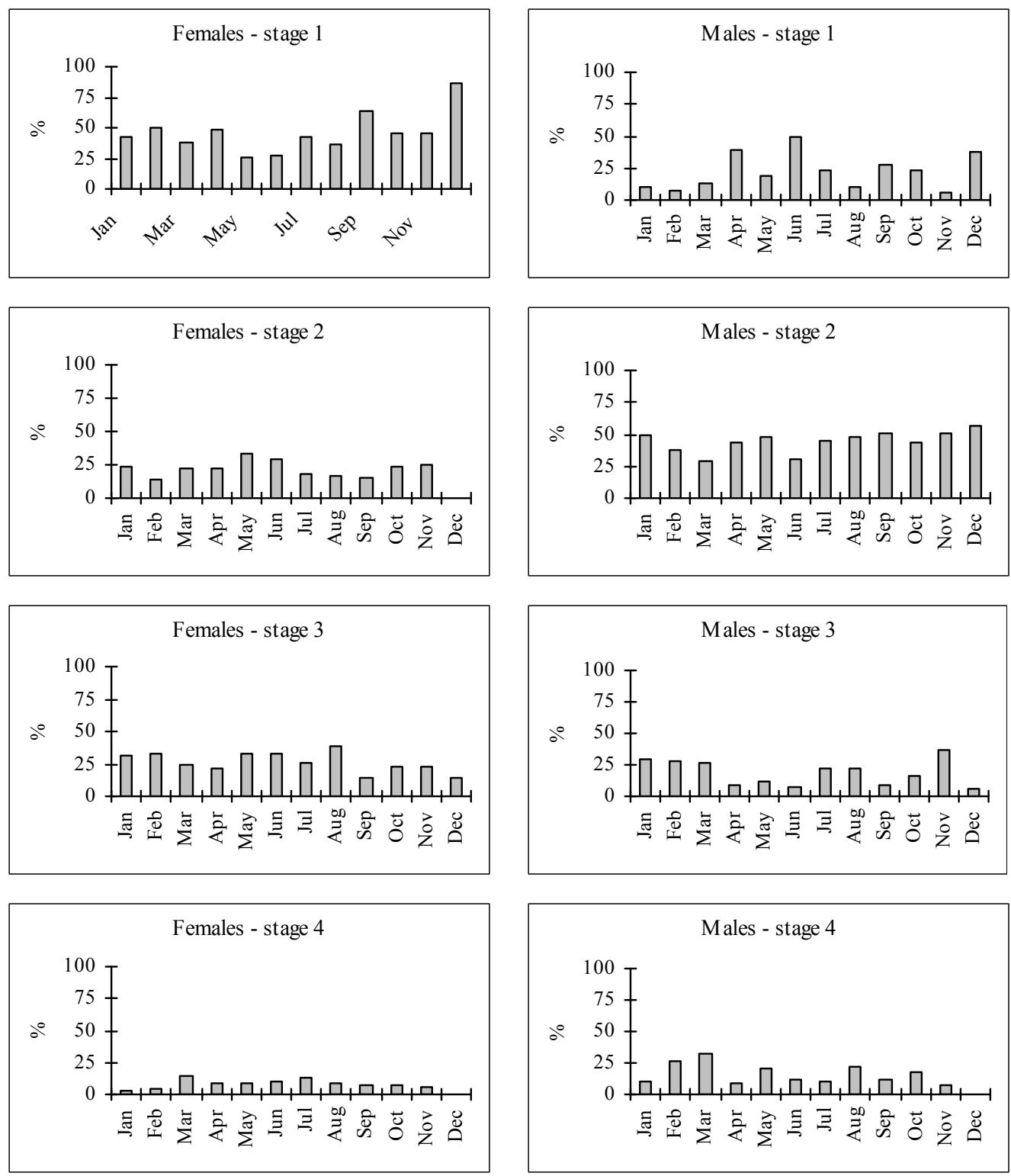

Figue 8. Maturity stages assigned de visu for females (left) and males (right) hake in the Portuguese Coast in the period 2005-2010. Maturity stages: 1) Immature or Resting; 2) Maturing; 3) Spawning; 4) Post-spawning. 
Table 9. Conversion factor for gutted weight (Wg) to Total Weight (Wt) by sex and by month for hake in the Portuguese coast in the period 2005-2010 (years are pooled by month).

\begin{tabular}{|c|c|c|c|c|c|}
\hline Month & Sex & Function & $\mathrm{N}$ & R2 (\%) & $\begin{array}{l}\text { Length range } \\
(\mathrm{cm})\end{array}$ \\
\hline \multirow{3}{*}{ January } & Males & 1.0889 & 105 & 0.989 & $26.2-49.9$ \\
\hline & Females & 1.1437 & 151 & 0.989 & $24.5-73.0$ \\
\hline & $\begin{array}{c}\text { Sexes } \\
\text { combined }\end{array}$ & 1.1329 & 269 & 0.989 & $24.5-73.0$ \\
\hline \multirow{3}{*}{ February } & Males & 1.0860 & 168 & 0.968 & $21.0-45.3$ \\
\hline & Females & 1.1661 & 227 & 0.984 & $20.3-77.0$ \\
\hline & $\begin{array}{c}\text { Sexes } \\
\text { combined }\end{array}$ & 1.1505 & 395 & 0.990 & $20.3-77.0$ \\
\hline \multirow{3}{*}{ March } & Males & 1.0880 & 218 & 0.987 & $20.0-52.0$ \\
\hline & Females & 1.1584 & 367 & 0.987 & $20.0-70.1$ \\
\hline & $\begin{array}{c}\text { Sexes } \\
\text { combined }\end{array}$ & 1.1511 & 612 & 0.989 & $18.1-70.1$ \\
\hline \multirow{3}{*}{ April } & Males & 1.0877 & 251 & 0.994 & $20.0-53.21$ \\
\hline & Females & 1.1494 & 680 & 0.992 & $20.0-77.5$ \\
\hline & $\begin{array}{c}\text { Sexes } \\
\text { combined }\end{array}$ & 1.1465 & 1073 & 0.994 & $11.0-77.5$ \\
\hline \multirow{3}{*}{ May } & Males & 1.1162 & 170 & 0.990 & $20.0-66.1$ \\
\hline & Females & 1.1576 & 409 & 0.989 & $20.0-74.0$ \\
\hline & $\begin{array}{c}\text { Sexes } \\
\text { combined }\end{array}$ & 1.1537 & 618 & 0.990 & $18.3-74.0$ \\
\hline \multirow{3}{*}{ June } & Males & 1.0852 & 75 & 0.994 & $20.0-47.2$ \\
\hline & Females & 1.1692 & 234 & 0.986 & $20.3-66.8$ \\
\hline & $\begin{array}{c}\text { Sexes } \\
\text { combined }\end{array}$ & 1.1661 & 344 & 0.990 & $20.0-66.8$ \\
\hline \multirow{3}{*}{ July } & Males & 1.0861 & 108 & 0.997 & $20.1-50.8$ \\
\hline & Females & 1.1538 & 388 & 0.992 & $20.0-82.8$ \\
\hline & $\begin{array}{c}\text { Sexes } \\
\text { combined }\end{array}$ & 1.1505 & 530 & 0.993 & $19.5-82.8$ \\
\hline \multirow{3}{*}{ August } & Males & 1.0986 & 93 & 0.992 & $21.9-60.7$ \\
\hline & Females & 1.1782 & 271 & 0.984 & $20.7-76.7$ \\
\hline & $\begin{array}{c}\text { Sexes } \\
\text { combined }\end{array}$ & 1.1691 & 376 & 0.988 & $20.7-76.7$ \\
\hline \multirow{3}{*}{ September } & Males & 1.1212 & 128 & 0.981 & $20.6-46.7$ \\
\hline & Females & 1.1558 & 326 & 0.991 & $20.1-67.8$ \\
\hline & $\begin{array}{c}\text { Sexes } \\
\text { combined }\end{array}$ & 1.1529 & 461 & 0.991 & $20.1-67.8$ \\
\hline \multirow{3}{*}{ October } & Males & 1.1111 & 92 & 0.985 & $20.1-49.0$ \\
\hline & Females & 1.5530 & 272 & 0.983 & $20.0-63.3$ \\
\hline & $\begin{array}{c}\text { Sexes } \\
\text { combined }\end{array}$ & 1.1523 & 365 & 0.986 & $20.0-63.3$ \\
\hline \multirow{3}{*}{ November } & Males & 1.0937 & 159 & 0.984 & $21.0-54.7$ \\
\hline & Females & 1.1471 & 221 & 0.991 & $20.4-77.0$ \\
\hline & $\begin{array}{c}\text { Sexes } \\
\text { combined }\end{array}$ & 1.1367 & 381 & 0.990 & $20.4-77.0$ \\
\hline \multirow{3}{*}{ December } & Males & 1.1226 & 32 & 0.949 & $24.5-39.2$ \\
\hline & Females & 1.2165 & 7 & 0.425 & $34.4-38.8$ \\
\hline & $\begin{array}{c}\text { Sexes } \\
\text { combined }\end{array}$ & 1.1586 & 39 & 0.954 & $24.5-39.2$ \\
\hline
\end{tabular}

Table 10. Pearson correlation coeficient of GSI, HSI and K for hake of the Portuguese coast calculated using the total and gutted weight in the period 2005-2010.

\begin{tabular}{cccc}
\hline Sex & $\begin{array}{c}\text { Correlation } \\
\text { factors }\end{array}$ & $\begin{array}{c}\text { Correlation } \\
\text { coeficient }(r)\end{array}$ & $\begin{array}{c}\text { Correlation type } \\
\text { (Cohen, 1988) }\end{array}$ \\
\hline Females & GSIt/CFt & -0.3 & Medium \\
& GSIt/HSIt & 0.5 & Strong \\
& HSIt/CFt & 0.1 & Weak \\
& GSIg/CFg & -0.6 & Strong \\
& GSIg/HSIg & -0.5 & Strong \\
& HSIg/CFg & -0.3 & Medium \\
Males & GSIt/CFt & -0.3 & Medium \\
& GSIt/HSIt & -0.4 & Medium \\
& HSIt/CFt & -0.3 & Medium \\
& GSIg/CFg & -0.6 & Strong \\
& GSIg/HSIg & -0.4 & Medium \\
& HSIg/CFg & -0.2 & Weak \\
\hline
\end{tabular}

Table 11. Peaks of hake spawning in the Portuguese coast in the period 2005-2010.

\begin{tabular}{cccc}
\hline Classes $(\mathrm{cm})$ & 1st peak & 2nd peak & 3rd peak \\
\hline Total & Mar. & May & Aug. \\
$20-30$ & Feb. & Jun. & Aug. \\
$31-40$ & Jan. & Jun. & Aug. \\
$41-50$ & Mar. & May & Aug. \\
$51-60$ & Jan. & Mar. & May \\
$>60$ & Jan. & Jun. & Sep. \\
\hline
\end{tabular}

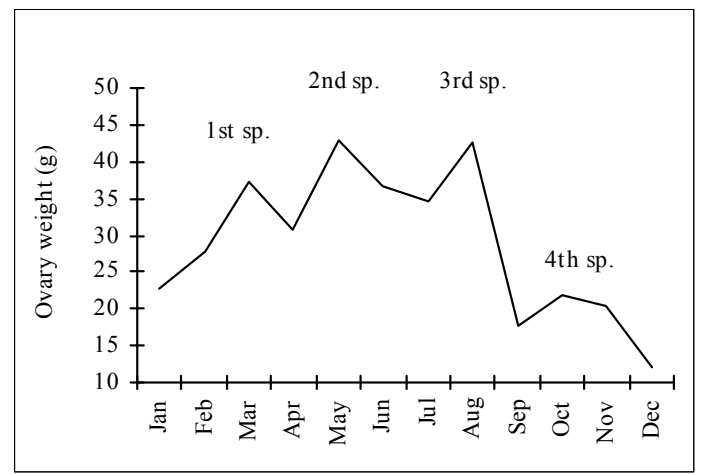

Figure 9. Monthly evolution of average ovarian weight of hake in the Portuguese Coast in the period 2005-2010 considering all the length classes.

culture production has recently increased (Groison, 2010 [55]; Hiney et al., 2002 [56]; Kjesbu et al., 2006 [57]). some researchers have even stated that the hake is one of 
the most promising new species for marine aquaculture (Engelsen et al., 2004) [58]. Recruitment indices of hake in the portuguese coast have been varying in the last decades, showing a decreasing trend from 1990 to 1995 , followed by a strong oscillation from 1995 onwards (Cardador et al., 2009) [59]. Maybe this is responsible for the decreasing catches verified at the middle of the 2000 decade. However, the recovery plan for the southern stock of hake implemented by the E.U. in 2006, as well as the ban on fishing in the portuguese waters between Milfontes and Arrifana, from the 1st of December to the last day of February for the protection of the juveniles, are most likely contributing to the increase of the abundance indices in the most recent years - an increase of $65 \%$ in 2007 compared with the previous years. Unlike juveniles, that distribute between 100 and 200 meters depth (Cardador et al., 2009) [59], bigger individuals, living at higher depths, are always caught in smaller numbers. In the present study fish with more than $50 \mathrm{~cm}$ total length corresponded to $19 \%$ and those with more than $60 \mathrm{~cm}$ corresponded to $5 \%$ of all the sampled specimens. Yet, these numbers may not reflect the size structure of the exploited population since the discards of the species Merluccius merluccius were very high in the years 2004-2005, 18\% (Fernandes et al., 2008) [60], while in 2007-2008 the discards of hake, mainly of individuals smaller then $27 \mathrm{~cm}$ (the legal minimum length) were higher then the species landings (Cardador et al., 2009) [59].

Similar observations are referred by Lucio et al. (1998) [61] for the Bay of Biscay, where only $10 \%$ of the captured fish were $45-49 \mathrm{~cm}$ and less than $5 \%$ had more than $60 \mathrm{~cm}$. Piñeiro et al. (1998) [62] also mention that very few individuals were caught with more than $60 \mathrm{~cm}$ in the ICES Div. VIIIc and IXa.

In the present study sex ratio for the length classes smaller than $40 \mathrm{~cm}$ was close to $1: 1$. In the individuals over $40 \mathrm{~cm}$ length females were predominant (1:0.13) while in the classes over $50 \mathrm{~cm}$ the abundance of females almost reached the $100 \%(1: 0.03)$. The several authors that refer the sex ratio of the different hake populations present, in some cases, results different from ours, stating that in length classes under $40 \mathrm{~cm}$ males are predominant. Piñeiro et al. (1998) [62], Sainza and Pérez (1998) [63] and Lucio et al. (1998) [61], studied the biology of demersal fish of the Bay of Biscay and the Cantabrian Sea, within the project BIOSDEF, and refer that in the length classes $25-45 \mathrm{~cm}$ prevailed the males, while in length classes $45-55 \mathrm{~cm}$ the proportion of the two sexes was of 1:1. A similar result was observed by Piñeiro and Sainza (2003) [48] in Iberian Atlantic waters corresponding to ICES divisions VIIIc and IXa for the individuals under $45 \mathrm{~cm}$ length, but for the bigger classes observations were slightly different, with the males out- numbering the females, after which females predominated and rapidly increased in relative abundance to reach $100 \%$ in fish larger than $60 \mathrm{~cm}$. Also El Habouz et al. (2011) [44], working with hake from the eastern central Atlantic, refer that the evolution of the sex ratio in the length class interval 17 to $45 \mathrm{~cm}$ was close to $1: 1$ and that only females were found over $45 \mathrm{~cm}$ length. Higher number of males for intermediate sizes and higher number of females for larger sizes has been observed by Fariña and Fernández (1986) [64] in the West of Ireland, in the Portuguese coast by Portuguese researchers during five years of surveys (ICES, 1982 [65], 1983 [66], 1986 [67], 1987 [68], 1988 [69]), as well as in the bay of Biscay by Martin (1991) [70] and Lucio et al. (1998) [61]. Sarano (1983) [71] states that in the Gulf of Gascony most of the smaller individuals were males, while the bigger fish were predominantly females. Finally, Angelescu et al. (1958) [72] show a proportion of 2:1 in favor of the females of the Argentine Sea. Despite these different observations, the results of all the authors indicate, just like ours, that in length classes over $60 \mathrm{~cm}$ the percentage of females reaches almost the $100 \%$. This can be due to the differences in the growth rates of the two sexes, the natural mortality rate of old males may be much higher than that of females or to the different behaviour and consequently different acessibility of fish (Piñeiro, 2011) [1]. Likewise, if male grow at a smaller rate, particularly after the start of reproduction the effect of growth and the mortality rate at length would lead to a bigger percentage of females at bigger length (Martin, 1991) [70]. Indeed, a recent study of the growth of European hake using tagging and recapture techniques (Mellon-Duval et al., 2010) [73] shows that from the second year of life, females grow faster than males.

The allometry coefficient is expressed by the exponent $b$ of the linear weight-length relationship equation. This relationship reflects an isometric growth when $b=3$, i.e., when the relative growth of both variables is perfectly identical (Mayrat, 1970 [74]; Ricker, 1973 [31], 1975 [32]). If $b<3$ we are in presence of a negative allometric growth and if $b>3$ we have a positive allometric growth (Sokal and Rohlf, 1987) [75]. In general, the estimates of length-weight relationships obtained in this study, based either on the total weight or the gutted weight, are close to those obtained by other authors in previous studies, not only for the portuguese coast but also for the adjacent areas of hake distribution (Cardador, 1988 [8]; Cardenas and Fernández, 1981 [76]; Godinho and Afonso, 1998 [77]; ICES, 1991 [78]; Lucio et al., 1998 [61]; Morey et al., 2003 [79]; Moutopoulos and Stergiou, 2002 [80]; Piñeiro et al., 1998 [62]; Piñeiro and Sainza, 2003 [48]; Santos et al., 2002 [13]). Most of the results reported are related to the relationships between total length and total weight and to both sexes combined. Only few authors 
present these relationships between total length and gutted weight and with reference to males and females separately (Godinho and Afonso, 1998 [77]; Lucio et al., 1998 [61]; Piñeiro and Sainza, 2003 [48]; Piñeiro et al., 1998 [62]). We also could not find any reference to these relationships on a monthly basis, which we consider to be important since the gonads weights, mainly the ovaries, may vary considerably according to the time of the year, in particular along the spawning season, when the ovaries undergo a high increase in weight. Other factors, such as food availability on fish growth (Mommsen, 1998) [81], spatial variation due to the influence of water quality (Sparre et al., 1989) [82] or feeding rate (Santos et al., 2002 [13]) can also affect the length-weight relationships. However, the parameter $b$ is characteristic of the species (Mayrat, 1970) [74] and generally does not vary significantly throughout the year, unlike the parameter $a$, which may very daily, seasonally and/or between different habitats (Bagenal and Tesch, 1978) [83]. So, we conclude that the observed differences with the values reported in other studies can be due to differences in the number of samples at length distribution margins, by the time of the year when sampling took place or to the selective characteristics of fishing gear. The conversion factor between gutted and total weights found in our study is of the same kind of the ones presented by Cardenas and Fernández (1981a) [84] for the ICES Divisions VIIIc and IXa and by Lucio et al. (1998) [61] for the Bay of Biscay in particular.

The condition factor gives a general idea of the body condition, in terms of weight, of the fish along the year. The results of the present study, similar to the results presented by other authors (Lucio et al., 1998 [61]; Murua, 2006 [85]; Pérez and Pereiro, 1985 [86]) seem to show that hake condition, considering either the total or the gutted weight, is higher in autumn (November/December), decreasing in winter and reaching its minimum in spring (April). The general pattern observed, similar for both sexes, although for males with less marked fluctuations, maybe due to the fact that in females there is a higher transfer of energy, expressed in terms of weight, to the development of the ovaries.

There are several indicators that, along with the condition factor, allow us to define the spawning season of a certain species, including the indexes of the somatic condition (GSI and HSI), the annual distribution of the maturity stages and the gonads weight. In the present study the distribution of the maturity stages along the year, in particular the occurrence of maturity stages 2 (maturing) and 3 (spawning), as well as the annual distribution of the gonads weight, seem to indicate that spawning lasts from January to August, although with several peaks. Gonadosomatic index expresses the maturity of the gonads and its higher values indicate that the gonads are developing, while its lower values indicate the end of the spawning period (Lahaye, 1972) [87]. During maturation the fat reserves accumulated in the liver during the HSI peaks are mobilized to the ovaries oogenesis and the hepatosomatic index decreases rapidly (Billard, 1979 [88]; Lahaye, 1972 [87]). In the present study, although this observation is not very clear, an increasing trend of the GSI can be seen along the first semester, while HSI showed a decreasing tendency. These observations are in accordance to the fact that the European hake is reproductively active for almost the entire year and spawning females are found all the year round (Murua and Motos, 2006) [46] and so the annual evolution of the two indexes is not as clear as in species with a shorter spawning season (El Habouz et al., 2011) [44].

The analysis of the total results of this study and considering the presence of maturity stage 1 (Immature or Resting), present throughout the year, and the monthly distribution of the weights of the gonads, it seems that the hake of the portuguese coast has a long spawning season, but where three stronger spawning peaks seem to be identified, March, May and August, and a weeker one in October. The same results are presented by Monteiro and Dias (1965) [3], who refer that female hakes from the Portuguese coast spawn all year around, with a higher intensity in Spring and Summer. Similar observations are pointed out by other authors that refer a long spawning season for the species Merluccius merluccius, as well as the presence of individuals mature and immature throughout the year (Al-Absawey, 2010 [89]; El Habouz et al., 2011 [44]; Piñeiro and Sainza, 2003 [48]). The winter spawning season has been observed previously in the Moroccan Atlantic (El Habouz, 1995 [90]; Ramos et al., 1990 [91], 1991 [92]), while Maurin (1954) [93] refered for the same area a longer spawning season, from December to the beginning of summer. Two peaks have also been observed in winter and summer in the CECAF area (Cervantes and Goñi, 1986) [94], January-February, and a secondary peak in summer, July-August, while a maximum spawning peak was observed from January to March on the north Atlantic Spanish coast (Perez and Pereiro, 1981 [95]) Piñeiro and Sainza, 2003 [48]) and in the Bay of Biscay (Murua and Motos, 2006 [46]). In the Mediterranean Sea, Bouhlal (1973) [96] observed a maximum spawning peak in winter and two othersmaller peaks in spring and late summer in the Gulf of Tunis, while Álvarez et al. (2001) [97] refer for the NE Atlantic that the spawning season extends from February to July. Other studies into the reproductive biology of European hake have indicated that this species spawns from January through July, along the shelf edge from the Bay of Biscay to the southwest of Ireland (Álvarez et al., 2004 [98]; Lucio et al., 2000 [99]; Martin, 1991 [70]). Other species of Merluccius, living in other geographical areas, also 
present long spawning seasons. M. hubbsi Marini, 1933, from the Patagonian waters, spawns from December to March, with a peak in January-February (Macchi et al., 2004 [100]); the spawning season of M. productus Ayres, 1855, from Canada, extends from February to June (Mason, 1986 [101]), while the results of Payá and Ehrhardt (2005) [102] and Landaeta and Castro (2012) [103] studying M. gayi gayi Guichenot, 1848 and M. australis Hutton, 1872, from the Chile indicate that the spawning season lasts from late summer to early autumn. In the NW Pacific $M$. albidus Mitchill, 1818, spawns from April to July (Traver et al., 2012 [104]). M. senegalensis Cadenat, 1950 and M. polli Cadenat, 1950, also called black hakes, are two species which distribution area overlaps with the European hake $M$. merluccius and which spawning season lasts from November to February (Fernández-Peralta et al., 2011 [51]).

This study addresses a set of reliable parameters that can be used to undertake new assessments filling the gap of information available on the reproductive biology of European hake inhabiting the Portuguese coast. After a detailed analysis we did not find significant differences in relation to the results presented by other authors, either for the Iberian Peninsula or the adjacent areas. This work can therefore be the basis for the development of other fields of study, more delimited in space or in time.

\section{Acknowledgements}

This work was supported by the PNAB/EU DCR-Data Collection Regulation. The author is grateful to Doctor Alberto Murta for his help with statistical analysis and all the technicians that along these years have performed the biological sampling that made this work possible.

\section{REFERENCES}

[1] C. Piñeiro, "Edad y Crecimiento de la Merluza Europea Merluccius merluccius (Linnaeus, 1758) del Noroeste de la Península Ibérica: Evolución de un Paradigma," Tesis Doctoral, Universidade de Vigo, Vigo, 2011.

[2] International Council for the Exploration of the Sea "Report of the Working Group on the Assessment of Southern Shelf Demersal Stocks," International Council for the Exploration of the Sea, Koepenhamn, 1996.

[3] R. Monteiro and M. Lima Dias, "On Some Aspects of the Ovary Development in the Hake (Merluccius merluccius L.) of the Portuguese Coast," International Council for the Exploration of the Sea, Koepenhamn, 1965.

[4] R. Monteiro and M. Lima Dias, "On Some Aspects of the Fecundity of the Hake (Merluccius merluccius L.) of the Portuguese Coast," International Council for the Exploration of the Sea, Koepenhamn, 1966.

[5] M. F. Cardador, "Factors Influencing the Distribution and Abundance of Hake (Merluccius Merluccius) in the Portuguese Waters (ICES, Div. IXa) Based on Groundfish
Surveys Data," International Council for the Exploration of the Sea, Koepenhamn, 1995.

[6] L. Ibaibarriaga, X. Irigoien, M. Santos, L. Motos, J. M. Fives, C. Franco, A. Lago de Lanzos, S. Acebedo, M. Bernal, N. Bez, G. Eltink and A. Farinha, "Egg and Larvae Distribution of Seven Fish Species in the North East Atlantic Waters," Fisheries Oceanography, Vol. 16, No. 3, 2007, pp. 284-293. doi:10.1111/j.1365-2419.2007.00430.x

[7] A. Campos and P. Fonseca, "Selectivity of Diamond and Square Mesh Cod Ends for Horse Mackerel (Trachurus trachurus), European Hake (Merluccius merluccius) and Axillary Seabream (Pagellus acarne) in the Shallow Groundfish Assemblage off the South-West Coast of Portugal," Scientia Marina, Vol. 67, No. 2, 2003, pp. 249-260.

[8] M. F. Cardador, "Estratégias de Exploração do Stock de Pescada (Merluccius merluccius L.) das Águas IberoAtlânticas. Efeitos em Stocks Associados. Dissertação Para Provas de Acesso à Categoria de Investigador Auxiliar," Instituto Nacional de Investigação das Pescas, Lisboa, 1988.

[9] M. F. Cardador, "Southern Stock of Hake (ICES Divisions VIIIc + IXa): Simulations of Different Fishing Strategies," International Council for the Exploration of the Sea, Koepenhamn, 1991.

[10] M. L. Dias and M. F. Cunha, "The Portuguese Fishery in the Southeast Atlantic (1982-1983) and Biological Studies on Hakes Merluccius capensis and M. paradoxus during 1984," Collection of Scientific Papers ICSEAF, Vol. 13, 1984, pp. 37-87.

[11] P. Fonseca, R. Martins, A. Campos and P. Sobral, "GillNet Selectivity off the Portuguese Western Coast," Fisheries Research, Vol. 73, No. 3, 2005, pp. 323-339. doi:10.1016/j.fishres.2005.01.015

[12] O. Moura and F. Cardador, "Pescada, Lagostim, Carapau E Sardinha da Costa Continental Portuguesa: Situação e Propostas de Gestão Para 2005," IPIMAR Divulgação, Lisboa, 2005.

[13] M. N. Santos, M. B. Gaspar, P. Vasconcelos and C. C. Monteiro, "Weight/Length Relationship for 50 Selected Fish Species of the Algarve Coast (Southern Portugal)," Fisheries Research, Vol. 59, No. 1-2, 2002, pp. 289-295. doi:10.1016/S0165-7836(01)00401-5

[14] A. M. Caramelo, "Results of the Young Hake Surveys in Portuguese Waters in October-November 1981-1982," International Council for the Exploration of the Sea, Koepenhamn, 1983.

[15] F. Cardador, M. F. Borges, C. Chaves and S. Groom, "Hake (Merluccius merluccius L.) Spatial and Temporal Recruitment Variability as a Key Species in the Portuguese Upwelling Ecosystem," International Council for the Exploration of the Sea, Koepenhamn, 2005.

[16] H. Mendes, M. F. Borges, C. L. Scott and C. Frid, "Climatic Impact on Hake Recruitment in Iberian Peninsula and Implications for Fisheries Management: An Inexfish Project Study," International Council for the Exploration of the Sea, Koepenhamn, 2008.

[17] M. L. Marecos, M. E. Vasconcelos, M. H. Diniz and C. C. Monteiro, "Reunião Sobre o Crescimento da Pescada, 
Verdinho e Carapau," Relatórios Técnicos e Científicos INIP, Lisboa, 1982.

[18] M. L. Godinho, M. H. Afonso and C. Morgado, "Age and Growth of Hake Merluccius merluccius Linnaeus, 1758 from the Northeast Atlantic (ICES division Ixa)," Boletino del Instituto Español de Oceanografia, Vol. 17, No. 3-4, 2001, pp. 255-262.

[19] E. Jardim, V. Trujillo and P. Sampedro, "Uncertainties in Sampling Procedures for Age Composition of Hake and Sardine in Iberian Atlantic Waters," Scientia Marina, Vol. 68, No. 4, 2004, pp. 561-569.

[20] M. Salgado, E. Jardim and M. A. Dias, "Study of Methods to Evaluate the Determination of Age Applied to Hake Merluccius merluccius of the Portuguese Coast," Relatórios Científicos e Técnicos, IPIMAR, Série Digital, Lisboa, 2003.

[21] A. M. Costa, E. Jardim, P. Gonçalves and C. Morgado, "Imaturo ou em Repouso? Implicações Nas Ogivas de Maturação da Pescada do Stock Sul," 2009. http://hdl.handle.net/10261/39081

[22] P. Gonçalves, M. E. Cunha and A. M. Costa, "Escala de Maturação Microscópica E Macroscópica Das Gónadas Femininas de Pescada (Merluccius merluccius)," Relatórios Científicos e Técnicos do IPIMAR, Série digital, Lisboa, 2004.

[23] A. M. Costa and P. Gonçalves, "Immature/Resting Macroscopic Misclassification: What Happens with the European Hake Males (Southern Stock Case)?” 2009. http://hdl.handle.net/10261/24937

[24] R. Dominguez-Petit, "Study of Reproductive Potential of Merluccius merluccius in the Galician Shelf," Doctoral Thesis, University of Vigo, Vigo, 2007.

[25] F. Saborido Rey and S. Junquera, "Histological Assessment of the Variations in Sexual Maturity of Cod (Gadus morhua) in Flemish Cap (Northwest Atlantic)," ICES Journal of Marine Science, Vol. 55, No. 3, 1998, pp. 515521. doi:10.1006/jmsc.1997.0344

[26] E. Marques, "A Copepod Parasite in the Hake," Garcia de Orta: Serie de zoologia, Vol. 12, No. 1-2, 1985, pp. 17-18.

[27] M. P. Silva, "Kudoa Sp. in the Muscle of Whiting (Merluccius merluccius (L.))," Repositório de Trabalhos do Laboratório Nacional de Investigação Veterinária (Portugal), Vol. 16, 1984, pp. 151-154.

[28] H. N. Cabral and A. G. Murta, "The Diet of Blue Whiting, Hake, Horse Mackerel and Mackerel off Portugal," Journal of Applied Ichthyology, Vol. 18, No. 1, 2001, pp. 14-23. doi:10.1046/j.1439-0426.2002.00297.x

[29] L. Hill and M. F. Borges, "A Comparison of the Seasonal Abundance of Hake (Merluccius merluccius) and Its Main Prey Species off the Portuguese Coast," International Council for the Exploration of the Sea, Koepenhamn, 2000.

[30] P. Gonçalves, N. M. Bandarra, M. Monteiro, A. M. Costa and E. Cunha, "Evolution of the Total Lipids in Muscle and Gonads of Hake (Merluccius merluccius) during Gonadal Development," International Council for the Exploration of the Sea, Koepenhamn, 2004.
[31] W. E. Ricker, "Linear Regressions in Fishery Research," Journal of Fisheries Research Board of Canada, Vol. 30, No. 3, 1973, pp. 409-434. doi:10.1139/f73-072

[32] W. E. Ricker, "Computation and Interpretation of Biological Statistics of Fish Populations," Journal of Fisheries Research Board of Canada, Vol. 191, 1975, pp. $202-$ 233.

[33] T. Fulton, "Rate of Growth of Sea Fish," 20th Annual Report of the Fishery Board for Scotland, London, 1902.

[34] G. West, "Methods of Assessing Ovarian Development in Fishes: A Review," Australian Journal of Marine and Freshwater Research, Vol. 41, No. 2, 1990, pp. 199-222. doi:10.1071/MF9900199

[35] International Council for the Exploration of the Sea, "Report of the International Council for the Exploration of the Sea/GLOBEC Working Group on Cod and Climate Change (WGCCC)," International Council for the Exploration of the Sea, Koepenhamn, 2007.

[36] J. Cohen, "Statistical Power Analysis for the Behavioral Sciences," Erlbaum, Hillsdale, 1988.

[37] J. Casey and J. Pereiro, "European Hake (M. merluccius) in the Northeast Atlantic," In: J. Alheit and T. J. Pitcher, Eds., Hake: Fisheries, ecology and markets, Chapman and Hall, London, 1995, pp. 125-148.

[38] International Council for the Exploration of the Sea, "Report of the Working Group on Assessment of Hake Stocks," International Council for the Exploration of the Sea, Koepenhamn, 1979.

[39] EU, "Relatório da Comissão ao Parlamento Europeu, ao Conselho, ao Comité Económico e Social Europeu e ao Comité das Regiões. Aplicação do Plano de Recuperação das Unidades Populacionais de Pescada do Sul e de Lagostins," 2011.

http://eur-lex.europa.eu/LexUriServ/LexUriServ.do?uri= COM:2011:0418:FIN:PT:PDF

[40] BIOSDEF, "Biological Studies of Demersal Fish," Final Report to the Commission of European Communities, Study Contract DGXIV, Bruxelles, 1998.

[41] F. Biagi, A. Cesarini, M. Sbrana and C. Viva, "Reproductive Biology and Fecundity of Merluccius merluccius (Linnaeus 1758) in the Northern Tyrrhenian Sea," Cahiers Options Méditerranéennes, Vol. 10, 1995, pp. 47- 48.

[42] H. de Pontual, A. L. Groison, C. Piñeiro and M. Bertignac, "Evidence of Underestimation of European Hake Growth in the Bay of Biscay, and Its Relationship with Bias in the Agreed Method of Age Estimation," International Council for the Exploration of the Sea Journal of Marine Science, Vol. 63, No. 9, 2006, pp. 1674-1681. doi:10.1016/j.icesjms.2006.07.007

[43] R. Domínguez-Petit, M. Korta, F. Saborido-Rey, H. Murua, M. Sainza and C. Piñeiro, "Changes in Size at Maturity of European Hake Atlantic Populations in Relation with Stock Structure and Environmental Regimes," Journal of Marine Systems, Vol. 71, No. 3-4, 2008, pp. 260278. doi:10.1016/i.jmarsys.2007.04.004

[44] H. El Habouz, L. Recasens, S. Kifani, A. Moukrim, A. Bouhaimi and S. El Ayoubi, "Maturity and Batch Fecundity of the European Hake (Merluccius merluccius, Lin- 
naeus, 1758) in the Eastern Central Atlantic," Scientia Marina, Vol. 75, No. 3, 2011, pp. 447-454. doi:10.3989/scimar.2011.75n3447

[45] M. Korta, R. Domínguez-Petit, H. Murua and F. SaboridoRey, "Regional Variability in Reproductive Traits of European Hake Merluccius merluccius L. Populations," Fisheries Research Special Issue, Vol. 104, No. 1-3, 2010, pp. 64-72.

[46] H. Murua and L. Motos, "Reproductive Strategy and Spawning Activity of the European Hake Merluccius merluccius (L.) in the Bay of Biscay," Journal of Fish Biology, Vol. 69, No. 5, 2006, pp. 1288-1303. doi:10.1111/j.1095-8649.2006.01169.x

[47] H. Murua, L. Motos and P. Lucio, "Reproductive Modality and Batch Fecundity of the European Hake (Merluccius merluccius L.) in the Bay of Biscay," CalCOFI Reports, Vol. 39, 1998, pp. 196-203.

[48] C. Piñeiro and M. A. Saínza, "Age Estimation, Growth and Maturity of the European Hake (Merluccius merluccius (Linnaeus, 1758)) from Iberian Atlantic waters," International Council for the Exploration of the Sea Journal of Marine Science, Vol. 60, No. 5, 2003, pp. 10861102. doi:10.1016/S1054-3139(03)00086-9

[49] F. Velasco and I. Olaso, "European Hake Merluccius merluccius (L., 1758) Feeding in the Cantabrian Sea: Seasonal, Bathymetric and Length Variations," Fisheries Research, Vol. 38, No. 1, 1998, pp. 33-44. doi:10.1016/S0165-7836(98)00111-8

[50] F. Balbontin and W. Fischer, "Sexual Cycle and Fecundity of the Hake, Merluccius gayi gayi, from the Coasts of Chile," Revue de Biologie Marine, Vol. 17, No. 3, 1981, pp. 285-334.

[51] L. Fernandéz-Peralta, F. Salméron, J. Rey, M. A. Puerto and R. García-Cancela, "Reprodutive Biology of Black Hakes (Merluccius polli and M. senegalensis) off Mauritania," Ciencias Marinas, Vol. 37, No. 4B, 2011, pp. 527546

[52] R. M. Honji, A. M. Vaz-dos-Santos and C. Rossi-Wongtschowski, "Identification of the Stages of Ovarian Maturation of the Argentine Hake Merluccius hubbsi Marini, 1933 (Teleostei: Merlucciidae): Advantages and Disadvantages of the Use of the Macroscopic and Microscopic Scales," Neotropical Ichthyology, Vol. 4, No. 3, 2006, pp. 329-337. doi:10.1590/S1679-62252006000300004

[53] L. O. Relini, C. Papaconstantinou, S. Jukic-Peladic, A. Souplet, L. G. de Sola, C. Piccinetti, S. Kavadas and M. Rossi, "Distribution of the Mediterranean Hake Populations (Merluccius merluccius smiridus Rafinesque, 1810) (Osteichthyes: Gadiformes) Based on Six Years Monitoring by Trawl-Surveys: Some Implications for Management," Scientia Marina, Vol. 66, No. S2, 2002, pp. 2138.

[54] FAO “Global Statistical Collections," 2010. http://www.fao.org/fishery/statistics/global-capture-produ ction/query/en

[55] A.-L. Groison, "Male Reproductive Biology of European Hake Merluccius merluccius," Ph.D. Dissertation, University of Bergen, Bergen, 2010.

[56] M. Hiney, H. Rodger, I. Brickell, P. Casburn and D.
Mulcahy, "Aquaculture Development and Regulation: Incompatibility or Harmony?" Bulletin of the European Association of Fish Pathologists, Vol. 22, No. 2, 2002, pp. 178-184.

[57] O. S. Kjesbu, G. L. Taranger and E. A. Trippel, "International Council for the Exploration of the Sea Gadoid Mariculture: Development and Future Challenges," Journal of Marine Science, Vol. 63, No. 2, 2006, pp. 187-191.

[58] R. Engelsen, F. Asche, F. Skjennum and G. Adoff, "New Species in Aquaculture: Some Basic Economic Aspects," In: E. Moksness, E. Kjørsvik and Y. Olsen, Eds., Culture of Cold-Water Marine Fish, Blackwell Publishing, Oxford, 2004, pp. 487-515. doi: $10.1002 / 9780470995617 . c h 12$

[59] F. Cardador, C. Chaves, C. Morgado and E. Jardim, "Recrutamento de Pescada em Águas Continentais Portuguesas," IPIMAR Divulgação, Lisboa, 2009.

[60] A. C. Fernandes, S. Barbosa, D. Silva and G. Pestana, "Composição dos Desembarques e das Rejeições por Espécie da Frota Portuguesa de Arrasto de Fundo," Relatórios Científicos e Técnicos do IPIMAR, Série digital, Lisboa, 2008.

[61] P. Lucio, M. Santurtún and H. Murua, "Growth and Reproduction of Hake (Merluccius merluccius) in the Bay of Biscay during 1996-1997," International Council for the Exploration of the Sea, Koepenhamn, 1998.

[62] C. Piñeiro, M. Sainza, J. Fontenla and I. Loureiro, "European Hake (Merluccius merluccius) from International Council for the Exploration of the Sea Division VIIIc and IXa and Sub-Areas VII," Final Report to the Commission of European Communities, Study Contract DGXIV, Bruxelles, 1998.

[63] M. Sainza and N. Pérez, "Preliminary Result of the Hake Reproduction (Merluccius merluccius) in International Council for the Exploration of the Sea Sub-Area VII," Final Report to the Commission of European Communities, Study Contract DGXIV, Bruxelles, 1998.

[64] A. C. Fariña and A. Fernández, "Datos Biologicos de la Merluza del Oeste de Irlanda," Informes Técnicos del Instituto Español de Oceanografia, Vol. 47, 1986, pp. 1-13.

[65] International Council for the Exploration of the Sea, "Report of the Working Group on Assessment of Hake Stocks," International Council for the Exploration of the Sea, Koepenhamn, 1982.

[66] International Council for the Exploration of the Sea, "Report of the Working Group on Assessment of Hake Stocks," International Council for the Exploration of the Sea, Koepenhamn, 1983.

[67] International Council for the Exploration of the Sea, "Report of the Working Group on Assessment of Hake Stocks," International Council for the Exploration of the Sea, Koepenhamn, 1986.

[68] International Council for the Exploration of the Sea, "Report of the Working Group on Assessment of Hake Stocks," International Council for the Exploration of the Sea, Koepenhamn, 1987.

[69] International Council for the Exploration of the Sea, "Report of the Working Group on Assessment of Hake 
Stocks," International Council for the Exploration of the Sea, Koepenhamn, 1988.

[70] I. Martin, "A Preliminary Analysis of Same Biological Aspects of Hake (Merluccius merluccius L. 1758) in the Bay of Biscay," International Council for the Exploration of the Sea, Koepenhamn, 1991.

[71] F. Sarano, "La Reproduction du Merlu Merluccius merluccius (L.): Cycle Ovarien et fécondité. Cycle Sexual de la Population du Golfe de Gascogne. These Présentée pour Obtenir le Titre de Docteur de 3e Cycle, "Université de Poitiers, Rochelle, 1983.

[72] V. Angelescu, F. S. Gneri, A. Nani, "La Merluza del Mar Argentino (Biologia y Taxonomia)," Universia, Buenos Aires, 1958.

[73] C. Mellon Duval, H. de Pontual, L. Metral and L. Quemener, "Growth of European Hake (Merluccius merluccius) in the Gulf of Lions Based on Conventional Tagging," ICES Journal of Marine Science, Vol. 67, No. 1, 2010, pp. 62-70. doi:10.1093/icesjms/fsp215

[74] A. Mayrat, "Allometrie et Taxonomie," Révue de Statistique Appliquée, Vol. 18, No. 4, 1970, pp. 47-58.

[75] R. R. Sokal and F. J. Rohlf, "Introduction to Biostatistics, 2nd Edition, Freeman, New York, 1987.

[76] E. Cardenas and A. Fernández, "Length/Girth and Length/ Weight Relationships of Hake in Divisions VIIIc + IXa," International Council for the Exploration of the Sea, Koepenhamn, 1981.

[77] M. L. Godinho and M. H. Afonso, "European Hake (Merluccius merluccius) from Portuguese Waters /International Council for the Exploration of the Sea Division IXa)," Final Report to the Commission of European Communities, Study Contract DGXIV, Bruxelles, 2001.

[78] International Council for the Exploration of the Sea, "Report of the Working Group on the Assessment of the Stocks of Hake," International Council for the Exploration of the Sea, Koepenhamn, 1991.

[79] G. Morey, J. Moranta, E. Massuti, A. Grau, M. Linde, F. Riera and B. Morales-Nin, "Weight-Length Relationships of Littoral to Lower Slope Fishes from the Western Mediterranean," Fisheries Research, Vol. 62, No. 1, 2003, pp. 89-96. doi:10.1016/S0165-7836(02)00250-3

[80] D. K. Moutopoulos and K. I. Stergiou, "Length-Weight and Length-Length Relationships of Fish Species from the Aegean Sea (Greece)," Journal of Applied Ichthyology, Vol. 18, No. 3, 2002, pp. 200-203. doi:10.1046/j.1439-0426.2002.00281.x

[81] T. P. Mommsen, "Growth and Metabolism," In: D. H. Evans, Ed., The Physiology of Fishes, CRC Press, New York, 1998, pp. 65-97.

[82] P. Sparre, E. Ursin and S. C. Venema, "Introduction to Tropical Fish Stock Assessment. Part I. Manual,” FAO Fisheries Technical Paper, New York, 1989.

[83] T. B. Bagenal and F. W. Tesh, "Age and growth," In: T. Bagenal, Ed., Methods for Asssessment of Fish Pro-duction in Freshwaters, Blackwell Scientific Publications, Oxford, 1978.

[84] E. Cardenas and A. Fernández, "La Relación Talla/Peso en la Merluza del Cantábrico y Galicia y su Evolución
Annual," Boletin del Instituto Español de Oceanografia, Vol. 2, No. 3, 1981, pp. 61-67.

[85] H. Murua, "Reproductive Fundamentals for the Estimation of Egg Production of the European Hake, Merluccius merluccius, in the Bay of Biscay," Ph.D. Dissertation, Universidad del País Vasco, Bilbao, 2006.

[86] N. Perez and F. J. Pereiro, "Reproductive Aspects of Hake (Merluccius merluccius L.) on the Galician and Cantabrian Shelves," Boletin del Instituto Español de Oceanografia, Vol. 2, No. 3, 1985, pp. 39-47.

[87] J. Lahaye, "Cycles Sexuels de Quelques Poissons Plats Des Côtes Bretonnes" Revue des Travaux de l'Institute des Pêches Maritimes, Vol. 36, No. 2, 1972, pp. 191-207.

[88] R. Billard, "La Gamétogenèse, le Cycle Sexuel et le Contrôle de la Reproduction chez les Poissons Téleosteens," Bulletin Français de la Pêche et de la Pisciculture, Vol. 273, 1979, pp. 117-136. doi:10.1051/kmae: 1979008

[89] M. Al-Absawey, "The Reproductive Biology and the Histological and Ultrastructural Characteristics in Ovaries of the Female Gadidae Fish Merluccius merluccius from the Egyptian Mediterranean Water," African Journal of Biotechnology, Vol. 9, No. 17, 2010, pp. 2544-2559.

[90] H. El Habouz "Étude de la Biologie Et la Dynamique Des Populations Du Merlu Blanc (Merluccius merluccius, Linnaeus 1758) Débarqué par les Chalutiers Côtiers au Port d'Agadir. Thèse de troisième Cycle. Option Océanographie Biologique," University Ibn Zohr, Agadir, 1995.

[91] A. Ramos, A. Cervantes and I. Sobrino, "Estudios Biológicos Sobre la Merluza Europea (Merluccius merluccius L., 1758) del Área de CECAF," FAO, COPACE/PACE, New York, 1990.

[92] A. Ramos, I. Sobrino and Y. L. Fernández, "Oceanography and Marine Resources in the Eastern Central Atlantic," ICCM, Palmas, 1996.

[93] C. Maurin, "Les Merlus du Maroc et Leur Pêche," Bulletin de l'Institut des Pêches Maritimes du Maroc, Vol. 2, 1954, pp. 7-65.

[94] A. Cervantes and R. Goñi, "Composición por Tallas de la Captura Española de Merluza Senegalesa (Merluccius senegalensis Cadenat 1950) y Merluza Negra (Merluccius cadenati Doutre, 1960) en el Área de CECAF, Año 1982," FAO, COPACE/PACE, New York, 1986.

[95] N. Perez and F. J. Pereiro, "First Data on Sexual Maturation and Sex Ratio of Hake (Merluccius merluccius L.) from International Council for the Exploration of the Sea Divisions VIIIc and IXa," International Council for the Exploration of the Sea, Koepenhamn, 1981.

[96] M. Bouhlal, "Le Merlu des Côtes Nord de la Tunisie: Etude Economique et Biologique (Reproduction, SexRatio et Répartition Bathymétrique)," Bulletin de l'Institut Océanographique et Pêche, Vol. 2, No. 4, 1973, pp. 579-603.

[97] P. Álvarez, J. Fives, L. Motos, and A. Uriarte, "Onshelf Transport of Hake, Merluccius merluccius, Eggs and Larvae in the NE Atlantic," International Council for the Exploration of the Sea, Koepenhamn, 2001.

[98] P. Álvarez, J. Fives, L. Motos, and M. Santos, "Distribution and Abundance of European Hake Merluccius mer- 
luccius (L.) Eggs and Larvae in the NorthEast Atlantic Waters in 1995 and 1998 in Relation to Hydrographic Conditions," Journal of Plankton Research, Vol. 26, No. 7, 2004, pp. 811-826. doi:10.1093/plankt/fbh074

[99] P. Lucio, H. Murua and M. Santurtún, "Growth and Reproduction of Hake (Merluccius merluccius) in the Bay of Biscay during 1996-1997," Ozeanografika, Vol. 3, 2000, pp. 325-354.

[100] G. Macchi, M. Pájaro and M. Ehrlich, "Seasonal Egg Production Pattern of the Patagonian Stock of Argentine Hake (Merluccius hubbsi)," Fisheries Research, Vol. 67, No. 1, 2004, pp. 25-38. doi:10.1016/j.fishres.2003.08.006

[101] J. C. Mason, "Fecundity of the Pacific Hake, Merluccius Productus, Spawning in Canadian Waters," Fishery Bulletin, Vol. 84, No. 1, 1986, pp. 209-216.

[102] I. Payá and N. M. Ehrhardt, "Comparative Sustainability Mechanisms of Two Hake (Merluccius gayi gayi and Merluccius australis) Populations Subjected to Exploitation in Chile," Bulletin of Marine Science, Vol. 76, No. 2, 2005, pp. 261-286.

[103] M. F. Landaeta and L. R. Castro, "Seasonal and Annual Variation in Chilean Hake Merluccius gayi Spawning Locations and Egg Size off Central Chile," Progress in Oceanography, Vol. 92, No. 1, 2012, pp. 166-177. doi:10.1016/i.pocean.2011.07.002

[104] M. Traver, L. Alade and K. A. Sosebee, "Population Biology of a Data Poor Species, Offshore Hake (Merluccius albidus) in the Northwest Atlantic, United States," Fish- eries Research, Vol. 114, 2012, pp. 42-51. doi:10.1016/j.fishres.2011.08.004

[105] DGPA, "Recursos da Pesca. Série Estatística, 1999” Direcção Geral das Pescas e Aquicultura, Brasília, 2000.

[106] DGPA, "Recursos da Pesca. Série Estatística, 2000," Direcção Geral das Pescas e Aquicultura, Brasília, 2001.

[107] DGPA, "Recursos da Pesca. Série Estatística, 2001,” Direcção Geral das Pescas e Aquicultura, Brasília, 2002.

[108] DGPA, "Recursos da Pesca. Série Estatística, 2002," Direcção Geral das Pescas e Aquicultura, Brasília, 2003.

[109] DGPA, "Recursos da Pesca. Série Estatística, 2003," Direcção Geral das Pescas e Aquicultura, Brasília, 2004.

[110] DGPA, "Recursos da Pesca. Série Estatística, 2004," Direcção Geral das Pescas e Aquicultura, Brasília, 2005.

[111] DGPA, "Recursos da Pesca. Série Estatística, 2005. Direcção Geral das Pescas e Aquicultura, Brasília, 2006.

[112] DGPA, "Recursos da Pesca. Série Estatística, 2006," Direcção Geral das Pescas e Aquicultura, Brasília, 2007.

[113] DGPA, "Recursos da Pesca. Série Estatística, 2007,” Direcção Geral das Pescas e Aquicultura, Brasília, 2008.

[114] DGPA, "Recursos da Pesca. Série Estatística, 2008," Direcção Geral das Pescas e Aquicultura, Brasília, 2009.

[115] DGPA, "Recursos da Pesca. Série Estatística, 2009," Direcção Geral das Pescas e Aquicultura, Brasília, 2010. 